\title{
COLD SPRING HARBOR SYMPOSIA ON QUANTITATIVE BIOLOGY VOLUME LXX
}




\section{www.cshl-symposium.org}

Institutions that have purchased the hardcover edition of this book are entitled to online access to the Symposium Web site. Please contact your institution's library to gain access to the Web site. The site contains the full text articles from the 2005 Symposium and the Symposia held in 1998-2004 as well as archive photographs and selected papers from the 61-year history of the annual Symposium.

If a token number is given above, you will need to activate the token to gain access. If you have previously registered and activated your online account for any prior volume without the use of a token, then you do not have to register again.

If you do not have an account number or a token number, or are experiencing access problems, please contact Kathy Cirone, CSHL Press Subscription Manager, at 1-800-843-4388, extension 4044 (Continental U.S. and Canada), 516-422-4100 (All other locations), cironek@cshl.edu, or subscriptionfeedback@symposium.org. 


\section{COLD SPRING HARBOR SYMPOSIA ON QUANTITATIVE BIOLOGY VOLUME LXX}

\section{Molecular Approaches to Controlling Cancer}

www.cshl-symposium.org 


\title{
COLD SPRING HARBOR SYMPOSIA ON QUANTITATIVE BIOLOGY VOLUME LXX
}

\author{
(C)2005 by Cold Spring Harbor Laboratory Press \\ International Standard Book Number 0-87969-773-3 (cloth) \\ International Standard Book Number 0-87969-774-1 (paper) \\ International Standard Serial Number 0091-7451 \\ Library of Congress Catalog Card Number 34-8174 \\ Printed in the United States of America \\ All rights reserved \\ COLD SPRING HARBOR SYMPOSIA ON QUANTITATIVE BIOLOGY \\ Founded in 1933 by \\ REGINALD G. HARRIS \\ Director of the Biological Laboratory 1924 to 1936 \\ Previous Symposia Volumes
}

I (1933) Surface Phenomena II (1934) Aspects of Growth III (1935) Photochemical Reactions

IV (1936) Excitation Phenomena

V (1937) Internal Secretions

VI (1938) Protein Chemistry

VII (1939) Biological Oxidations

VIII (1940) Permeability and the Nature of Cell Membranes

IX (1941) Genes and Chromosomes: Structure and Organization

X (1942) The Relation of Hormones to Development

XI (1946) Heredity and Variation in Microorganisms

XII (1947) Nucleic Acids and Nucleoproteins

XIII (1948) Biological Applications of Tracer Elements

XIV (1949) Amino Acids and Proteins

XV (1950) Origin and Evolution of Man

XVI (1951) Genes and Mutations

XVII (1952) The Neuron

XVIII (1953) Viruses

XIX (1954) The Mammalian Fetus: Physiological Aspects of Development

XX (1955) Population Genetics: The Nature and Causes of Genetic Variability in Population

XXI (1956) Genetic Mechanisms: Structure and Function

XXII (1957) Population Studies: Animal Ecology and Demography

XXIII (1958) Exchange of Genetic Material: Mechanism and Consequences

XXIV (1959) Genetics and Twentieth Century Darwinism

XXV (1960) Biological Clocks

XXVI (1961) Cellular Regulatory Mechanisms

XXVII (1962) Basic Mechanisms in Animal Virus Biology

XXVIII (1963) Synthesis and Structure of Macromolecules

XXIX (1964) Human Genetics

XXX (1965) Sensory Receptors

XXXI (1966) The Genetic Code

XXXII (1967) Antibodies

XXXIII (1968) Replication of DNA in Microorganisms

XXXIV (1969) The Mechanism of Protein Synthesis
XXXV (1970) Transcription of Genetic Material

XXXVI (1971) Structure and Function of Proteins at the Threedimensional Level

XXXVII (1972) The Mechanism of Muscle Contraction

XXXVIII (1973) Chromosome Structure and Function

XXXIX (1974) Tumor Viruses

XL (1975) The Synapse

XLI (1976) Origins of Lymphocyte Diversity

XLII (1977) Chromatin

XLIII (1978) DNA: Replication and Recombination

XLIV (1979) Viral Oncogenes

XLV (1980) Movable Genetic Elements

XLVI (1981) Organization of the Cytoplasm

XLVII (1982) Structures of DNA

XLVIII (1983) Molecular Neurobiology

XLIX (1984) Recombination at the DNA Level

L (1985) Molecular Biology of Development

LI (1986) Molecular Biology of Homo sapiens

LII (1987) Evolution of Catalytic Function

LIII (1988) Molecular Biology of Signal Transduction

LIV (1989) Immunological Recognition

LV (1990) The Brain

LVI (1991) The Cell Cycle

LVII (1992) The Cell Surface

LVIII (1993) DNA and Chromosomes

LIX (1994) The Molecular Genetics of Cancer

LX (1995) Protein Kinesis: The Dynamics of Protein Trafficking and Stability

LXI (1996) Function \& Dysfunction in the Nervous System

LXII (1997) Pattern Formation during Development

LXIII (1998) Mechanisms of Transcription

LXIV (1999) Signaling and Gene Expression in the Immune System

LXV (2000) Biological Responses to DNA Damage

LXVI (2001) The Ribosome

LXVII (2002) The Cardiovascular System

LXVIII (2003) The Genome of Homo sapiens

LXVIX (2004) Epigenetics

Front Cover (Paperback): Detail of a French anticancer poster, "Vaincre le Cancer," by Bernard Vellemot (courtesy of the National Library of Medicine).

Authorization to photocopy items for internal or personal use, or the internal or personal use of specific clients, is granted by Cold Spring Harbor Laboratory Press, provided that the appropriate fee is paid directly to the Copyright Clearance Center (CCC). Write or call CCC at 222 Rosewood Drive, Danvers, MA 01923 (978-750-8400) for information about fees and regulations. Prior to photocopying items for educational classroom use, contact CCC at the above address. Additional information on CCC can be obtained at CCC Online at http://www.copyright.com/

All Cold Spring Harbor Laboratory Press publications may be ordered directly from Cold Spring Harbor Laboratory Press, 500 Sunnyside Boulevard, Woodbury, NY 11797-2924. Phone: 1-800-843-4388 in Continental U.S. and Canada. All other locations: (516) 422-4100. FAX: (516) 422-4097. E-mail: cshpress@cshl.edu. For a complete catalog of all Cold Spring Harbor Laboratory Press publications, visit our World Wide Web Site http://www.cshlpress.com/

Web Site Access: Institutions that have purchased the hardcover edition of this book are entitled to online access to the companion Web site at www.cshl-symposium.org. For assistance with activation, please contact Kathy Cirone, CSHL Press Subscription Manager, at cironek@cshl.edu. 


\section{Symposium Participants}

Abate-Shen, Cory, Dept. of Medicine, UMDNJ-Robert Wood Johnson Medical School, Piscataway, New Jersey Aburatani, Hiroyuki, Lab. for Systems Biology and Medicine, University of Tokyo, Tokyo, Japan

ACKERMAN, ANN

ADAms, David, Dept. of Informatics, The Wellcome Trust Sanger Institute, Hinxton, Cambridge, United Kingdom

AdAMS, JERry, Molecular Genetics of Cancer, Walter and Eliza Hall Institute of Medical Research, Melbourne, Victoria, Australia

Aikhionbare, Felix, Dept. of Medicine, Morehouse School of Medicine, Atlanta, Georgia

Al-Haju, Muhammad, Oncology Disease Area, Novartis Institutes for BioMedical Research, Cambridge, Massachusetts

Alberts, BRUCE, Dept. of Biochemistry and Biophysics, University of California, San Francisco

Allio, Theresa, Dept. of Mouse Genome Informatics, The Jackson Laboratory, Bar Harbor, Maine

Allison, JAMES, Immunology Program, Howard Hughes Medical Institute, Memorial Sloan-Kettering Cancer Center, New York, New York

Amariglio, NinetTe, Dept. of Pediatric Hematology and Oncology, Chaim Sheba Medical Center, Tel Hashomer, Israel

Amson, RoBert, Dept. of Cancer Research, Molecular Engines Laboratories, Paris, France

Andl, Claudia, Dept. of Medicine and Genetics, University of Pennsylvania, Philadelphia

AnN, DAvid, Dept. of Molecular Pharmacology and Toxicology, University of Southern California, Los Angeles, California

Antonova, Lilia, Dept. of Pathology and Molecular Medicine, Queen's University, Kingston, Ontario, Canada

Arai, Yoshio, Dept. of Radiation Oncology, Veteran's Administration Medical Center, University of Pittsburgh, Pittsburgh, Pennsylvania

Armanios, Mary, Dept. of Oncology, Johns Hopkins University School of Medicine, Baltimore, Maryland

Arnone, MArc, Dept. of Oncology Biology, GlaxoSmithKline, Collegeville, Pennsylvania

ArVA, Nicoleta, Dept. of Biology, Hunter College, City University of New York, New York

Ashrenazi, Avi, Dept. of Molecular Oncology, Genentech, Inc., South San Francisco, California

Ashworth, Alan, The Breakthrough Breast Cancer Research Centre, Chester Beatty Laboratories, Institute of Cancer Research, London, United Kingdom

AtTAR, Richardo, Dept. of Oncology Drug Discovery, Bristol-Myers Squibb, Princeton, New Jersey
AtTARdi, Laura, Dept. of Radiation Oncology, Stanford University, Stanford, California

Aubin, REMY, Div. of Cell and Molecular Biology, Health Products and Food Biologicals Branch, Centre for Biologics Research, Health Canada, Ottawa, Ontario, Canada

Austin, Rick, Dept. of Biology, Amgen, Inc., South San Francisco, California

BADER, ANDrEAs, Dept. of Molecular and Experimental Medicine, The Scripps Research Institute, La Jolla, California

BAGCHI, ANINDYA, Cold Spring Harbor Laboratory, Cold Spring Harbor, New York

BAKIn, Andrei, Dept. of Cancer Genetics, Roswell Park Cancer Institute, Buffalo, New York

Ballesteros, Anita, Cancer Cell, Cell Press, Cambridge, Massachusetts

BANSAL, SANJAY, Dept. of Pharmacology and Therapeutics, Roswell Park Cancer Institute, Buffalo, New York

BARbaCid, Mariano, Centro Nacional de investigaciones Ontologica, Madrid, Spain

Bargonetti, Jill, Dept. of Biological Sciences, Hunter College, City University of New York, New York

BARnhart, Bryan, Dept. of Cancer Biology, University of Pennsylvania, Philadelphia

BAylin, StePhen, Oncology Center, Johns Hopkins University School of Medicine, Baltimore, Maryland

BeACHy, PhILIP, Dept. of Molecular Biology and Genetics, Johns Hopkins University School of Medicine, Baltimore, Maryland

Benezra, Robert, Dept. of Cell Biology, Memorial Sloan-Kettering Cancer Center, New York, New York

Bentivegna, Steven, Dept. of Pharmacogenomics, Pfizer, Inc., Groton, Connecticut

Benton, Geoffrey, Dept. of Pathology, University of California, San Francisco

Benvenuti, Silvia, The Oncogenomics Center, Institute for Cancer Research and Treatment, Candiolo, Torino, Italy

Benzinger, Anne, Dept. of Molecular Oncology, MaxPlanck-Institute for Biochemistry, Martinsried, Germany

Berberich, Matthew, Dept. of Molecular Biophysics and Biochemistry, Yale University, New Haven, Connecticut

Bernards, René, Dept. of Molecular Carcinogenesis, The Netherlands Cancer Institute, Amsterdam, The Netherlands

Berns, Anton, Dept. of Molecular Genetics, The Netherlands Cancer Institute, Amsterdam, The Netherlands

BeVErLy, LEVI, Dept. of Molecular and Cellular Oncogenesis, The Wistar Institute, Philadelphia, Pennsylvania 
Bihani, TeEru, Dept. of Molecular Pharmacology and Cancer Therapeutics, Roswell Park Cancer Institute, Buffalo, New York

Billottet, Clotilde, Dept. of Cell Signalling, Ludwig Institute for Cancer Research, London, United Kingdom

Bishop, J. Michael, Dept. of Microbiology, University of California, San Francisco

Bissell, MinA, Div. of Life Sciences, Lawrence Berkeley National Laboratory, Berkeley, California

BitTinger, Mark, Dept. of Target Support and Validation, Merck Research Laboratories, Boston, Massachusetts

BLANK, JuTTA, Dept. of Discovery Technologies, Novartis Institutes for BioMedical Research, Basel, Switzerland

Blume-Jensen, Peter, Dept. of Molecular Oncology, Merck Research Laboratories, Boston, Massachusetts

Bommi-Reddy, Archana, Dept. of Medical Oncology, Dana-Farber Cancer Institute, Boston, Massachusetts

Borzillo, Gary, Dept. of Cancer Biology, Pfizer, Inc., Groton, Connecticut

Brachmann, Saskia, Dept. of Medical Oncology, DanaFarber Cancer Institute, Boston, Massachusetts

BRADY, MARK, Dept. of Surgery and Oncology, University of Liverpool, Liverpool, United Kingdom

BrahmbHatt, Himanshu, Dept. of Cancer Research, EnGeneIC Pty, Ltd., Sydney, New South Wales, Australia

BREnNer, Sydney, The Salk Institute for Biological Studies, La Jolla, California

Briesewitz, Roger, Dept. of Pharmacology, Ohio State University, Columbus, Ohio

Brugge, JoAn, Dept. of Cell Biology, Harvard Medical School, Boston, Massachusetts

Brummer, Tilman, Cancer Research Program, Garvan Institute of Medical Research, Darlinghurst, Sydney, New South Wales, Australia

Burgess, DARREN, Cold Spring Harbor Laboratory, Cold Spring Harbor, New York

Burns, Alexander, Metabolic Diseases Branch, National Institute of Diabetes and Digestive and Kidney Diseases, National Institutes of Health, Bethesda, Maryland

Butt, Alison, Cancer Research Program, Garvan Institute of Medical Research, Darlinghurst, Sydney, New South Wales, Australia

CAI, WeI-Wen, Dept. of Molecular and Human Genetics, Baylor College of Medicine, Houston, Texas

CAmpbell, Robert, Dept. of Scientific Computing, Serono Research Institute, Rockland, Massachusetts

CAMPISI, Judith, Div. of Life Sciences, Lawrence Berkeley National Laboratory, Berkeley, California

CAO, LIU, Genetics of Development and Diseases Branch, National Institute of Diabetes and Digestive and Kidney Diseases, National Institutes of Health, Bethesda, Maryland

CApobianco, Anthony, Dept. of Molecular and Cellular Oncogenesis, The Wistar Institute, Philadelphia, Pennsylvania

Caputto, Beatriz, Dept. of Biological Chemistry, CIQUIBIC, National University of Córdoba, Córdoba, Argentina

CARMANY, GEORGE

Carriere, Catherine, Dept. of Medicine, Dartmouth
Medical School, Lebanon, New Hampshire

Chan, Kelvin, Dept. of Obstetrics and Gynecology, University of Hong Kong, Hong Kong

Chen, Emily, Dept. of Cell Biology, The Scripps Research Institute, La Jolla, California

Cheung, AnN, Center for Cancer Research, Massachusetts Institute of Technology, Cambridge, Massachusetts

Chodankar, Rajas, Prostate Cancer Center, CedarsSinai Medical Center, Los Angeles, California

Chong, Shaorong, Dept. of Research, New England BioLabs, Inc., Beverly, Massachusetts

Chou, Chen-Kung, Dept. of Life Science, Chang Gung University, Tao-Yuan, Taiwan, Republic of China

Cochran, AndreA, Dept. of Protein Engineering, Genentech, Inc., South San Francisco, California

Cochran, Brent, Dept. of Physiology, Tufts University School of Medicine, Boston, Massachusetts

Collier, LARA, Dept. of Genetics, Cell Biology and Development, Cancer Center, University of Minnesota, Minneapolis

Comb, Michael, President, Cell Signaling Technology, Beverly, Massachusetts

Connell, Laureen, Genes \& Development, Cold Spring Harbor Laboratory Press, Cold Spring Harbor, New York

COOMBER, DAVID, Institute of Molecular and Cellular Biology, Proteos, Singapore

Coopman, Peter, Unité Mixte de Recherche, Centre National de la Recherche Scientifique, University of Montpellier, Montpellier, France

Coqueret, Oliver, Cancer Center Paul Papin, INSERM, Angers, France

Cormier, CATHERINe, Cold Spring Harbor Laboratory, Cold Spring Harbor, New York

Courtneidge, SARA, Cell Adhesion and Extracellular Matrix Program, The Burnham Institute, La Jolla, California

Covello, Kelly, Dept. of Cell and Developmental Biology, University of Pennsylvania, Philadelphia

CraWford, Sarah, Dept. of Biology, Southern Connecticut State University, New Haven, Connecticut

Crawford, YongPIng, Dept. of Angiogenesis Research, Genentech, Inc., South San Francisco, California

Cullinan, Emily, Dept. of Oncology, Lexicon Genetics, Inc., The Woodlands, Texas

CURTIS, DANIEL, Dept. of Developmental and Molecular Pathways, Novartis Institutes for BioMedical Research, Cambridge, Massachusetts

DACKOUR, RADUWAN, Dept. of Otolaryngology, Long Island Jewish Medical Center, New Hyde Park, New York

DAI, CHEngKaI, Whitehead Institute for Biomedical Research, Cambridge, Massachusetts

DAKIC, AleKsAndAR, Dept. of Immunology, Walter and Eliza Hall Institute of Medical Research, Parkville, Victoria, Australia

DAnKort, David, Cancer Research Institute, Comprehensive Cancer Center, University of California, San Francisco

DAs, BIKUL, Dept. of Hematology and Oncology, Hospital for Sick Children, Toronto, Ontario, Canada

DE Lange, Titia, Dept. of Cell Biology and Genetics, Rockefeller University, New York, New York

DePinho, Ronald, Dept. of Medical Oncology, Dana- 
Farber Cancer Institute, Boston, Massachusetts

De Sauvage, Frederic, Dept. of Molecular Oncology, Genentech, Inc., South San Francisco, California

Dey, Anwesha, Institute of Molecular and Cell Biology, Proteos, Singapore

Dickins, Ross, Cold Spring Harbor Laboratory, Cold Spring Harbor, New York

Dillin, Andrew, Lab. of Molecular and Cell Biology, The Salk Institute for Biological Studies, La Jolla, California

Di Marcotullio, Lucia, Dept. of Experimental Medicine and Pathology, University La Sapienza, Rome, Italy

Draetta, Giulio, Dept. of Cancer Research, Merck Research Laboratories, Boston, Massachusetts

Drageset, ViLde, Dept. of Genetics, The Norwegian Radium Hospital, Oslo, Norway

Du, YI-ChIEH NANCY, Dept. of Cancer Biology and Genetics, Memorial Sloan-Kettering Cancer Center, New York, New York

DuAn, ZHENFEnG, Dept. of Hematology and Oncology, Massachusetts General Hospital, Boston, Massachusetts

Ebert, JoAn, Cold Spring Harbor Laboratory Press, Woodbury, New York

EILERS, MARTIN, Institute of Molecular Biology and Tumor Research, University of Marburg, Marburg, Germany

EInBond, LindA, Dept. of Rehabilitation Medicine, Columbia University, New York, New York

EISENMAN, Robert, Div. of Basic Sciences, Fred Hutchinson Cancer Research Center, Seattle, Washington

Elledge, Stephen, Dept. of Genetics, Harvard Medical School, Boston, Massachusetts

Emery, Caroline, Dept. of Medical Oncology, DanaFarber Cancer Institute, Boston, Massachusetts

Enomoto, TAKeharu, Lineberger Comprehensive Cancer Center, University of North Carolina, Chapel Hill

EPPING, MiRJam, Dept. of Molecular Carcinogenesis, The Netherlands Cancer Institute, Amsterdam, The Netherlands

Epstein, Charles, Cambridge Genomics Center, SanofiAventis, Cambridge, Massachusetts

Erdmann, Dirk, Dept. of Oncology, Novartis Pharma AG, Basel, Switzerland

ERnKVIST, MirA, Dept of Oncology and Pathology, Karolinska Institute, Stockholm, Sweden

Evan, GERARD, Dept. of Cellular and Molecular Pharmacology, Cancer Research Institute, Comprehensive Cancer Center, University of California, San Francisco

Faga, Giovanni, Dept. of Experimental Oncology, European Institute of Oncology, Milan, Italy

FAN, Hung, Dept. of Molecular Biology and Biochemistry, Cancer Research Institute, University of California, Irvine

FEINBERG, ANDrew, Epigenetics Unit, Johns Hopkins University School of Medicine, Baltimore, Maryland

Ferbeyre, Gerardo, Dept. of Biochemistry, Université de Montréal, Montréal, Québec, Canada

Fero, Matthew, Div. of Clinical Research, Fred Hutchinson Cancer Research Center, Seattle, Washington

FlanNERY, ANGELA, Dept. of Genetic Research and Development, AstraZeneca, Macclesfield, United Kingdom

Flavell, Madlyn, Guilford, Connecticut

FlaVell, Richard, Dept. of Immunobiology, Yale Uni- versity School of Medicine, New Haven, Connecticut

FolKMAN, JUDAH, Dept. of Surgery, Children's Hospital, Harvard Medical School, Boston, Massachusetts

Foreman, Kenneth, Dept. of Cancer Chemistry, OSI Pharmaceuticals, Inc., Farmingdale, New York

Fournier, Alaina, Dept. of Pharmacology, University of Pennsylvania, Philadelphia

Fridman, Jordan, Dept. of Preclinical Biology, Incyte Corporation, Wilmington, Delaware

Friedman, Lori, Dept. of Research, Genentech, Inc., South San Francisco, California

FrIEND, StePhen, Dept. of Molecular Profiling and Cancer Research, Merck Research Laboratories, West Point, Pennsylvania

Futreal, Andrew, Cancer Genome Project, The Wellcome Trust Sanger Institute, Hinxton, Cambridge, United Kingdom

Galaktionov, Konstantin, Dept. of Molecular and Human Genetics, Baylor College of Medicine, Houston, Texas

Galloway, Denise, Dept. of Cancer Biology, Fred Hutchinson Cancer Research Center, Seattle, Washington

Gann, Alexander, Cold Spring Harbor Laboratory Press, Woodbury, New York

Gann, Lilian, Cold Spring Harbor Laboratory, Cold Spring Harbor, New York

GaO, ZhiJiAn, Dept. of Hematology and Oncology, Massachusetts General Hospital, Boston, Massachusetts

GaO, HuI, Biosciences NOVUM, Karolinska Institute, Huddinge, Sweden

GARY, Sydney, Cold Spring Harbor Laboratory, Cold Spring Harbor, New York

GeIGer, Thomas, Dept. of Molecular Genetics, The Netherlands Cancer Institute, Amsterdam, The Netherlands

Gerhard, Daniela, National Cancer Institute, National Institutes of Health, Bethesda, Maryland

GiBson, NeIL, Dept. of Research, OSI Pharmaceuticals, Inc., Farmingdale, New York

Gil, German, Dept. of Pediatrics, Robert Wood Johnson Medical School, Cancer Institute of New Jersey, New Brunswick, New Jersey

GIL, JEsus, Cold Spring Harbor Laboratory, Cold Spring Harbor, New York

Girnun, Geoffrey, Dept. of Cancer Biology, Dana-Farber Cancer Institute, Harvard Medical School, Boston, Massachusetts

Godbole, Madan, Dept. of Endocrinology, Sanjay Gandhi Postgraduate Institute of Medical Sciences, Lucknow, India

Goelet, Phillip, Road to the Cure, San Diego, California

GOLDBERG, ITZHAK, Dept. of Radiation Oncology, Long Island Jewish Medical Center, New Hyde Park, New York

Gonzalez, Michael, Medical Research Council Cancer Cell Unit, Hutchison/MRC Research Centre, Cambridge, United Kingdom

Gordan, JoHn, Abramson Family Cancer Research Institute, University of Pennsylvania, Philadelphia, Pennsylvania

Gorovits, NAIRA, Cold Spring Harbor Laboratory, Cold Spring Harbor, New York

Gorrini, Chiara, Dept. of Experimental Oncology, 
European Institute of Oncology, Milan, Italy

Gradi, Alessandra, Dept. of Molecular Oncogenesis, Regina Elena Cancer Institute, Rome, Italy

Graeber, Thomas, Dept. of Molecular and Medical Pharmacology, University of California, Los Angeles

GRAHAM, RoBERT, Victor Chang Cardiac Research Institute, Darlinghurst, Sydney, Australia

Grausenburger, Reinhard, Dept. of Medical Biochemistry, Medical University of Vienna, Vienna, Austria

Gray, JoE, Lawrence Berkeley National Laboratory, Berkeley, California and University of California, San Francisco

GreIDER, CAROL, Dept. of Molecular Biology and Genetics, Johns Hopkins University School of Medicine, Baltimore, Maryland

Grossel, Martha, Dept. of Zoology, Connecticut College, New London, Connecticut

Gruber, Michaela, Abramson Family Cancer Research Institute, University of Pennsylvania, Philadelphia

Grubor, Vladimir, Cold Spring Harbor Laboratory, Cold Spring Harbor, New York

Grueneberg, Dorre, RNAi Consortium, Broad Institute, Massachusetts Institute of Technology, Cambridge, Massachusetts

Guardiola-Serrano, Francisca, Dept. of Molecular Hematology, University of Frankfurt Medical School, Frankfurt am Main, Germany

GuO, BING, Dept. of Oncology Research, Wyeth, Pearl River, New York

Guo, Ailan, Dept. of Research, Cell Signaling Technology, Beverly, Massachusetts

GuPTA, PIYUsh, Dept. of Biology, Whitehead Institute for Biomedical Research, Massachusetts Institute of Technology, Cambridge, Massachusetts

HA, TAEKJIP, Dept. of Physics, University of Illinois, Urbana

Haber, DANiEl, Cancer Center, Massachusetts General Hospital, Charlestown, Massachusetts

HabiB, TANIA, Dept. of Comparative Medicine, University of Washington, Seattle

Hagemeier, Christian, Children's Hospital, Charité, Humboldt-University, Berlin, Germany

Hahn, Meinhard, Dept. of Molecular Genetics, German Cancer Research Center, Heidelberg, Germany

Haley, JoHn, Dept. of Translational Research, OSI Pharmaceuticals, Inc., Farmingdale, New York

Hall, Mark, Dept. of Biochemistry, St. Jude Children's Research Hospital, Memphis, Tennessee

HALL, IRA, Cold Spring Harbor Laboratory, Cold Spring Harbor, New York

HAMLIN, Joyce, Dept. of Biochemistry and Molecular Genetics, School of Medicine, University of Virginia, Charlottesville

Han, TAE-HeE, Dept. of Molecular Cell Biology, Sungkyunkwan University School of Medicine, Suwon, South Korea

Hanahan, Douglas, Dept. of Biochemistry and Biophysics, University of California, San Francisco

Hannon, Gregory, Cold Spring Harbor Laboratory, Cold Spring Harbor, New York

HARLOW, ED, Dept. of Biological Chemistry and Molecular Pharmacology, Harvard University School of Medicine, Boston, Massachusetts
Harris, Crafford, Dept. of Drug Discovery, R.W. Johnson Pharmaceutical Research Institute, Raritan, New Jersey

HE, LIN, Cold Spring Harbor Laboratory, Cold Spring Harbor, New York

Hemann, Michael, Cold Spring Harbor Laboratory, Cold Spring Harbor, New York

Herbert, TAsino, Dept. of Biology, Southern Connecticut State University, New Haven, Connecticut

Hergovich Lisztwan, JoAnna, Novartis Pharma AG, Basel, Switzerland

Herman, James, Bunting Blaustern Cancer Research Center, Sidney Kimmel Comprehensive Cancer Center, Johns Hopkins University School of Medicine, Baltimore, Maryland

HeRMEKIng, Heiko, Dept. of Molecular Oncology, MaxPlanck-Institute for Biochemistry, Martinsried, Germany

Herschkowitz, JAson, Dept. of Genetics and Molecular Biology, University of North Carolina, Chapel Hill

Heuer, Timothy, Dept. of Cellular Pharmacology, Exelixis, Inc., South San Francisco, California

Hickey, Michele, Dept. of Cell and Molecular Biology, University of Pennsylvania, Philadelphia

Hicks, JAMES, Cold Spring Harbor Laboratory, Cold Spring Harbor, New York

Hill, Reginald, Dept. of Genetics, Lineberger Comprehensive Cancer Center, University of North Carolina, Chapel Hill

Hillan, Kenneth, Dept. of Research, Genentech, Inc., South San Francisco, California

Hippo, YoshitaKA, Cold Spring Harbor Laboratory, Cold Spring Harbor, New York

Hoffmann, IngRID, Dept. of Cell Cycle Control and Carcinogenesis, German Cancer Research Center, Heidelberg, Germany

Hohenade, Christine, Research Institute of Virology and Biomedicine, University of Veterinary Medicine, Vienna, Austria

Holst, Charles, Dept. of Molecular Oncology, Genentech, Inc., South San Francisco, California

Hu, Zhiyuan, Dept. of Genetics, Lineberger Comprehensive Cancer Center, University of North Carolina, Chapel Hill

Huang, ChI-Ying, Dept. of Molecular and Genomic Medicine, National Health Research Institutes, Zhunan, Taiwan, Republic of China

HuANG, FeI, Dept. of Oncology Biomarkers and Clinical Discovery Technology, Bristol-Myers Squibb, Princeton, New Jersey

Hughes, Christina, Dept. of Medical Oncology, DanaFarber Cancer Institute, Boston, Massachusetts

IACOvides, Demetris, Comprehensive Cancer Center, University of California, San Francisco

IANARI, Alessandra, Dept. of Experimental Medicine and Pathology, University La Sapienza, Rome, Italy

IGGO, RichaRD, Dept. of Molecular Oncology, Swiss Institute for Experimental Cancer Research, Epalinges, Switzerland

Inglis, John, Cold Spring Harbor Laboratory Press, Woodbury, New York

IsHIDA, SEIKO, Dept. of Biochemistry, Comprehensive Cancer Center, University of California, San Francisco 
Ishov, Alexander, Dept. of Anatomy and Cell Biology, University of Florida, Gainesville

ITO, YoshIAKI, RUNX Study Group, Institute of Molecular and Cell Biology, Proteos, Singapore

ITOH, REINA, Dept. of Tumor Virology, Research Institute for Microbial Disease, Osaka University, Osaka, Japan

IwaKuma, Tomoo, Dept. of Molecular Genetics, M.D. Anderson Cancer Center, University of Texas, Houston

Iwata, Kenneth, Dept. of Cancer Research, OSI Pharmaceuticals, Inc., Uniondale, New York

JACKS, TYleR, Center For Cancer Research, Howard Hughes Medical Institute, Massachusetts Institute of Technology, Cambridge, Massachusetts

JAKUBCZAK, JOHN, Pfizer Global Research and Development, Pfizer, Inc., Groton, Connecticut

Jane-Valbuena, Judit, Dept. of Medical Oncology, Dana-Farber Cancer Institute, Boston, Massachusetts

JAT, PAMJIT, Dept. of Neurodegenerative Disease, Institute of Neurology, University College, London, United Kingdom

JeChlinger, Martin, Dept. of Cancer Biology and Genetics, Memorial Sloan-Kettering Cancer Center, New York, New York

Ji, PENG, Dept. of Developmental and Molecular Biology, Albert Einstein College of Medicine, Bronx, New York

JoHnson, LEISA, Dept. of Molecular Biology, Genentech, Inc., South San Francisco, California

JOHNSON, MARK

Johnson, Tom, Dept. of Radiation Oncology, Stanford University, Stanford, California

Joukov, Vladimir, Dept. of Cancer Biology, Dana-Farber Cancer Institute, Boston, Massachusetts

Joyce, Johanna, Dept. of Cancer Biology and Genetics, Memorial Sloan-Kettering Cancer Center, New York, New York

Junttila, Melissa, Dept. of Medical Biochemistry, University of Turku, Turku, Finland

KACZMAREK, LeONARD, Dept. of Pharmacology, Yale University School of Medicine, New Haven, Connecticut

Kaelin, William, Dept. of Adult Oncology, Dana-Farber Cancer Institute, Boston, Massachusetts

Kакимото, Күоко, Dept. of Molecular Oncology, Osaka Bioscience Institute, Osaka, Japan

Kalluri, Raghu, Dept. of Medicine, Beth Israel Deaconess Medical Center, Boston, Massachusetts

Kalpana, Ganjam, Dept. of Molecular Genetics, Albert Einstein College of Medicine, Bronx, New York

Kalra, Deepak, Dept. of Cardiology, Children's Hospital, Harvard Medical School, Boston, Massachusetts

Kamata, Tohru, Dept. of Molecular Biology and Biochemistry, Shinshu University School of Medicine, Matsumoto, Japan

Kan, Julie, Dept. of Cancer Biology, OSI Pharmaceuticals, Inc., Farmingdale, New York

KAng, Hyung-GyoO, Dept. of Pathology, Children's Hospital, University of Southern California, Los Angeles, California

Kannius-Janson, Marie, Dept. of Cell and Molecular Biology, Gothenburg University, Gothenburg, Sweden

KARLSEDER, JAN, Dept. of Regulatory Biology, The Salk
Institute for Biological Studies, La Jolla, California

Karreth, Florian, Abramson Family Cancer Research Institute, University of Pennsylvania, Philadelphia

Kastan, Michael, Dept. of Hematology and Oncology, St. Jude Children's Research Hospital, Memphis, Tennessee

KenNy, PARAIC, Div. of Life Sciences, Lawrence Berkeley National Laboratory, Berkeley, California

Kiberstis, Paula, Science, American Association for the Advancement of Science, Washington, D.C.

KIM, JiYOUNG, Dept. of Biochemistry, Tufts University School of Medicine, Boston, Massachusetts

Kim, Marianne, Dept. of Medicine, Mount Sinai School of Medicine, New York, New York

KIng, MARY-Claire, Div. of Medical Genetics, University of Washington, Seattle

Kiviharju, Taija, Molecular Cancer Biology Program, University of Helsinki, Helsinki, Finland

KiYOKAWA, ETsuko, Dept. of Tumor Virology, Research Institute for Bacterial Diseases, University of Osaka, Osaka, Japan

Kogiso, Toмomi, International Medical Center of Japan, Tokyo, Japan

KondURI, SANTHI, Dept. of Pharmacology and Therapeutics, Roswell Park Cancer Instititute, Buffalo, New York

Kotanides, Helen, Dept. of Molecular and Cell Biology, ImClone Systems, Inc., New York, New York

Krucher, Nancy, Dept. of Biology, Pace University, Pleasantville, New York

Kuilman, Thomas, Dept. of Molecular Genetics, The Netherlands Cancer Institute, Amsterdam, The Netherlands

Kumar, Chandra, Dept. of Tumor Biology, ScheringPlough Research Institute, Kenilworth, New Jersey

KURKI, SARI, Molecular Cancer Biology Program, University of Helsinki, Helsinki, Finland

LADANYI, Marc, Dept. of Pathology, Memorial SloanKettering Cancer Center, New York, New York

LaMontagne, Kenneth, Drug Discovery, Johnson and Johnson Pharmaceutical Research and Development, Raritan, New Jersey

LANDER, ERIC, The Broad Institute, Massachusetts Institute of Technology, Cambridge, Massachusetts

LANe, KeARA, Center for Cancer Research, Massachusetts Institute of Technology, Cambridge, Massachusetts

LANE, DAVID, Executive Director, Institute of Molecular and Cell Biology, Proteos, Singapore

LeE, Chang Woo, Research Institute, National Cancer Center, Goyang, South Korea

LeE, Soyoung, Dept. of Hematology and Oncology, Charité, Universitätsmedizin Berlin, Berlin, Germany

LEES, JACQuEline, Dept. of Biology, Center for Cancer Research, Massachusetts Institute of Technology, Cambridge, Massachusetts

LeHMKUHL, KristinA, Dept. of Biological Sciences, Ohio University, Athens, Ohio

Leng, MeI, Dept. of Biochemistry, Baylor College of Medicine, Houston, Texas

LEPrince, Dominique, Lille Institute of Biology, Centre National de la Recherche Scientifique, Lille, France

Letai, Anthony, Dept. of Medical Oncology, Dana- 
Farber Cancer Institute, Boston, Massachusetts

LEVINE, ARnold, School of Natural Sciences, Institute for Advanced Studies, Princeton, New Jersey

Li, Xingnan, Dept. of Cell Biology, University of Alabama, Birmingham

LI, Rong, Dept. of Biochemistry and Molecular Genetics, University of Virginia, Charlottesville

Lin, Athena, Dept. of Pharmacology and Therapeutics, Roswell Park Cancer Institute, Buffalo, New York

LIN, LING, Metabolic Diseases Branch, National Institute of Diabetes and Digestive and Kidney Diseases, National Institutes of Health, Bethesda, Maryland

Lindemann, RalPh, Lab. of Gene Regulation, Cancer Immunology Program, Peter MacCallum Cancer Centre, East Melbourne, Victoria, Australia

LiU, Huiping, Ben May Institute for Cancer Research, University of Chicago, Chicago, Illinois

LiU, Jianhong, Dept. of Biology, MethylGene, Inc., Montréal, Québec, Canada

LiU, Kun-Hsiang, Dept. of Genomics, Biomedical Engineering Center, Industrial Technology Research Institute, Hsinchu, Taiwan, Republic of China

LiU, Xiangdong, Dept. of Drug Discovery and Development, Incyte Corporation, Wilmington, Delaware

LiU, Xuesong, Dept. of Cancer Research, Abbott Laboratories, Abbott Park, Illinois

LiU, Xuesong, Dept. of Oncology, Lexicon Genetics, Inc., The Woodlands, Texas

LiU, YING, Dept. of Cancer and Immunogenetics, Weatherall Institute of Molecular Medicine, J.R. Hospital, Oxford, United Kingdom

LiU, ZHAOLI, Dept. of Cell Biology, University of Alabama, Birmingham

Livingston, DAVID, Dept. of Cancer Biology, Dana-Farber Cancer Institute, Harvard School of Medicine, Boston, Massachusetts

Lowe, Scott, Howard Hughes Medical Institute, Cold Spring Harbor Laboratory, Cold Spring Harbor, New York

LU, XIN, Dept. of Molecular Biology, Princeton University, Princeton, New Jersey

LU, XIN, Lab. of Tumour Suppression, Ludwig Institute for Cancer Research, London, United Kingdom

LuCiani, Gloria, Dept. of Internal Medicine, Medical University of Vienna, Vienna, Austria

LuK, JoHN, Dept. of Surgery, University of Hong Kong, Hong Kong

Lyons, Jesse, Comprehensive Cancer Center, University of California, San Francisco

LÜSCHER, BERNHARD, Dept. of Biochemistry and Molecular Biology, RWTH University, Aachen, Germany

MacDiarmid, Jennifer, Dept. of Cancer Research, EnGeneIC Pty, Ltd., Sydney, New South Wales, Australia

MacDonald, Gwen, Dept. of Biochemistry, Cancer Research Institute, Queen's University, Kingston, Ontario, Canada

MACLEOD, KAY, Ben May Institute for Cancer Research, University of Chicago, Chicago, Illinois

Majid, AneEla, Toxicology Unit, Medical Research Council, Leicester, United Kingdom

Majumder, SAdhan, Dept. of Molecular Genetics, M.D. Anderson Cancer Center, University of Texas, Houston
Marcus, Emilie, Cell, Cell Press, Cambridge, Massachusetts

Margalit, Ofer, Dept. of Pediatric Hematology and Oncology, Chaim Sheba Medical Center, Tel-Hashomer, Israel

Marine, JeAn-Christophe, Lab. for Molecular Cancer Biology, Flanders Interuniversity Institute for Biotechnology, Ghent, Belgium

Markovina, Stephanie, Dept. of Medicine and Hematology, University of Wisconsin, Madison

Marshall, Deborah, Dept. of Oncology Research, Centocor, Inc., Radnor, Pennsylvania

Marte, Barbara, Nature, Nature Publishing Group, London, United Kingdom

Martin, Steven, Dept. of Molecular and Cell Biology, University of California, Berkeley

Martins, Carla, Comprehensive Cancer Center, University of California, San Francisco

Massagué, Joan, Dept. of Cell Biology, Genetics Program, Memorial Sloan-Kettering Cancer Center, New York, New York

MasudA, KazUhiRo, BioFrontier Laboratories, Kyowa Hakko Kogyo Co., Ltd., Tokyo, Japan

MATAPURKAR, ANAGHA, Cold Spring Harbor Laboratory, Cold Spring Harbor, New York

MazureK, Anthony, Cold Spring Harbor Laboratory, Cold Spring Harbor, New York

McCormick, Frank, Cancer Research Institute, Comprehensive Cancer Center, University of California, San Francisco

McLean, Adele, Dept. of Molecular Genetics, Institute of Biomedical and Life Sciences, University of Glasgow, Glasgow, Scotland, United Kingdom

McMahon, Martin, Cancer Research Institute, Comprehensive Cancer Center, University of California, San Francisco

Meani, Natalia, FIRC Institute of Molecular Oncology Foundation, European Institute of Oncology, Milan, Italy

Medico, Enzo, Institute for Cancer Research and Treatment, University of Torino School of Medicine, Candiolo, Torino, Italy

Mellman, Ira, Dept. of Cell Biology, Yale University School of Medicine, New Haven, Connecticut

MendozA, MichaEL, Div. of Digestive Diseases, University of California, Los Angeles

Menon, RadHA, Dept. of Immunology and Molecular Diagnostics, Federal Drug Administration, Rockville, Maryland

Meyerson, Matthew, Dept. of Molecular Oncology, Dana-Farber Cancer Institute, Boston, Massachusetts

Miller, Abigail, Cancer Research Institute, Comprehensive Cancer Center, University of California, San Francisco

Mills, Alea, Cold Spring Harbor Laboratory, Cold Spring Harbor, New York

Miranti, Cindy, Dept. of Microbiology,Van Andel Research Institute, Grand Rapids, Michigan

MischeK, Daniela, Research Institute of Virology and Biomedicine, University of Veterinary Medicine, Vienna, Austria

Mitra, Koyel, Dept. of Molecular Genetics, Albert Ein- 
stein College of Medicine, Bronx, New York

Mittal, ViveK, Cold Spring Harbor Laboratory, Cold Spring Harbor, New York

MoHI, M. Golam, Dept. of Medicine, Div. of Hematology and Oncology, Beth Israel Deaconess Medical Center, Boston, Massachusetts

Monkkonen, Mia, Molecular Cancer Biology Program, University of Helsinki, Helsinki, Finland

MoORES, SHERI, Dept. of Oncology and Supportive Care, GlaxoSmithKline, Collegeville, Pennsylvania

MORFORD, LORRI, Dept. of Microbiology, Immunology and Molecular Genetics, University of Kentucky, Lexington

MorI, SEIICHI, Institute for Genome Sciences and Policy, Duke University, Durham, North Carolina

Moroni, Maria Cristina, Dept. of Experimental Oncology, European Institute of Oncology, Milan, Italy

Morrison, Debra, Dept. of Medicine, Mount Sinai School of Medicine, New York, New York

Morrison, SEAn, Howard Hughes Medical Institute, University of Michigan, Ann Arbor

MroczKowski, BARBARA, Dept. of Structural Biology, Pfizer Global Research and Development, Pfizer, Inc., San Diego, California

Mu, DAvid, Cold Spring Harbor Laboratory, Cold Spring Harbor, New York

Mujtaba, Syed, Dept. of Physiology and Biophysics, Mount Sinai School of Medicine, New York, New York

Murphy, DANiEl, Cancer Research Institute, Comprehensive Cancer Center, University of California, San Francisco

Muthuswamy, Senthil, Cold Spring Harbor Laboratory, Cold Spring Harbor, New York

Mysinger, CynthiA, Cancer Research Institute, University of California, San Francisco

Nagahara, Hikaru, Sanno Hospital, International University of Health and Welfare, Tokyo, Japan

NAHLE, ZAHER, Dept. of Internal Medicine, Washington University, St. Louis, Missouri

NakadA, Daisuke, Div. of Biological Science, Nagoya University Graduate School of Science, Nagoya, Japan

NAKAdE, KoJI, BioResource Center, RIKEN, Ibaraki, Japan

Nakagama, Hitoshi, Div. of Biochemistry, National Cancer Center Research Institute, Tokyo, Japan

NARAmura, Mayumi, Dept. of Medicine, ENH Research Institute, Evanston, Illinois

NARITA, MAsaKo, Cold Spring Harbor Laboratory, Cold Spring Harbor, New York

NARITA, MASASHI, Cold Spring Harbor Laboratory, Cold Spring Harbor, New York

Navin, Nicholas, Cold Spring Harbor Laboratory, Cold Spring Harbor, New York

NeILl, Ushma, Journal of Clinical Investigation, Columbia University, New York, New York

NiCASSIO, Francesco, FIRC Institute Molecular Oncology Foundation, European Institute of Oncology, Milan, Italy

Nilsson, Jeanette, Dept. of Cell and Molecular Biology, Gothenburg University, Gothenburg, Sweden

Nolan, DaniEl, Cold Spring Harbor Laboratory, Cold Spring Harbor, New York

NunEZ, SABrinA, Cold Spring Harbor Laboratory, Cold
Spring Harbor, New York

OH, Hyun Jung, Dept. of Biological Sciences, Korea Advanced Institute of Science and Technology, Daejeon, South Korea

OH, SANG-PHIL, Dept. of Biological Sciences, Korea Advanced Institute of Science and Technology, Daejeon, South Korea

OHTA, Norio, BioFrontier Laboratories, Kyowa Hakko Kogyo Co., Ltd., Tokyo, Japan

Olive, Kenneth, Abramson Family Cancer Research Institute, University of Pennsylvania, Philadelphia

Olofsson, Beatrix, Dept. of Biochemistry, Drexel University College of Medicine, Philadelphia, Pennsylvania

Oneyama, Chitose, Lab. of Molecular Oncology, Osaka Bioscience Institute, Osaka, Japan

Opavsky, Rene, Dept. of Human Cancer Genetics, Ohio State University, Columbus, Ohio

O'Shea, Clodagh, Comprehensive Cancer Center, University of California, San Francisco

Ozer, Harvey, University Hospital Cancer Center, UMDNJ-New Jersey Medical School, Newark, New Jersey

Palakurthi, Sangeetha, Dept. of Cancer Bioscience, AstraZeneca, Waltham, Massachusetts

Pandolfi, Pier-Paolo, Memorial Sloan-Kettering Cancer Center, New York, New York

Papageorgis, Panagiotis, Dept. of Genetics and Genomics, Boston University School of Medicine, Boston, Massachusetts

PARADA, Luis, Center for Developmental Biology, Southwestern Medical Center, University of Texas, Dallas

PARK, JAehong, Dept. of Biological Chemistry and Molecular Pharmacology, Institute of Proteomics, Harvard Medical School, Cambridge, Massachusetts

PAVLETICH, NiKOLA, Structural Biology Program, Memorial Sloan-Kettering Cancer Center, New York, New York

Pende, Mario, Necker Institute, INSERM, Paris, France

Persson, Jenny, Dept. of Laboratory Medicine, Div. of Pathology, Lund University, Malmö, Sweden

Pervin, Shehla, Dept. of Obstetrics and Gynecology, University of California, Los Angeles

Peters, Gordon, Dept. of Molecular Oncology, London Research Institute, London, United Kingdom

Peterson, Jane, Div. of Extramural Research, National Human Genome Research Institute, National Institutes of Health, Bethesda, Maryland

Phan, Vernon, Cancer Research Institute, Comprehensive Cancer Center, University of California, San Francisco

Philbrick, William, Technical Advisory Committee, Yale University School of Medicine, New Haven, Connecticut

Piccini, Antonella, Cold Spring Harbor Laboratory, Cold Spring Harbor, New York

Pickering, Curtis, Dept. of Pathology, University of California, San Francisco

Pierce, Aisling, Dept. of Molecular Biology, National Institute for Cellular Biotechnology, Dublin City University, Dublin, Ireland

Podsypanina, Katrina, Dept. of Cell Biology, Memorial Sloan-Kettering Cancer Center, New York, New York 
Polakiewicz, Roberto, Dept. of Research, Cell Signaling Technology, Beverly, Massachusetts

Politi, Katerina, Dept. of Cancer Biology and Genetics, Memorial Sloan-Kettering Center, New York, New York

Pollock, Mila, Cold Spring Harbor Laboratory Library, Cold Spring Harbor, New York

Ponder, Bruce, Dept. of Oncology, Hutchison/MRC Research Centre, Cambridge, United Kingdom

Poortinga, Gretchen, Div. of Research, Peter MacCallum Cancer Centre, East Melbourne, Victoria, Australia

Porter, Jess, School of Medicine, University of Pennsylvania, Philadelphia

Powers, ScotT, Cold Spring Harbor Laboratory, Cold Spring Harbor, New York

Prives, Carol, Dept. of Biological Sciences, Columbia University, New York, New York

QIAN, YuEWEI, Lilly Research Laboratories, Eli Lilly and Company, Indianapolis, Indiana

Quon, KIM, Dept. of Biology, Amgen, Inc., South San Francisco, California

Rabbitts, Pamela, Dept. of Medicine, Medical School, University College, London, United Kingdom

RabBitts, Terence, Lab. of Molecular Biology, Medical Research Council, Cambridge, United Kingdom

Rabinovsky, Rosalia, Dept. of Medical Oncology, Dana-Farber Cancer Institute, Boston, Massachusetts

RAFFAniello, Robert, Dept. of Medical Laboratory Sciences, School of Health Professions, Hunter College, City University of New York, New York

Ramsey, Matthew, Dept. of Genetics, University of North Carolina, Chapel Hill

RAUCH, Jens, Molecular Oncology Clinical Cooperation Group, Ludwig-Maximilians University of Munich, Munich, Germany

RaUHALA, HanNA, Institute of Medical Technology, University of Tampere, Tampere, Finland

Rechavi, Gideon, Dept. of Pediatric Hematology and Oncology, Chaim Sheba Medical Center, TelHashomer, Israel

Repellin, Claire, Dept. of Molecular Genetics, University of Glasgow, Glasgow, Scotland, United Kingdom

Richardson, Celeste, Dept. of Oncology, Novartis Institutes for BioMedical Research, Cambridge, Massachusetts

Richmond, Jodi, Dept. of Pharmacogenomics, Pfizer, Inc., Groton, Connecticut

Rikova, Klarisa, Dept. of Research, Cell Signaling Technology, Beverly, Massachusetts

Roberts, Charles, Dept. of Pediatric Oncology, DanaFarber Cancer Institute, Boston, Massachusetts

Roche, Serge, Centre de Recherches de Biochimie Macromoléculaire, Centre National de la Recherche Scientifique, Montpellier, France

Rodriguez, Elena, Dept. of Molecular and Cell Biology, University of California, Berkeley

Rodriguez, Roberto, Dept. of Vascular Biology, Children's Hospital, Boston, Massachusetts

Roof, David, Dept. of Molecular and Cell Biology, Cytokinetics, Inc., South San Francisco, California

Rottmann, SABINE, Dept. of Cell and Cancer Biology,
Genomics Institute of the Novartis Research Foundation, San Diego, California

Rozenblatt-Rosen, Orit, Dept. of Molecular Oncology, Dana-Farber Cancer Institute, Boston, Massachusetts

Ruefli-Brasse, Astrid, Dept. of Biology, Amgen, Inc., South San Francisco, California

Ruggieri, Rosamaria, Dept. of Oncology and Cell Biology, North Shore-Long Island Jewish Institute for Medical Research, Manhasset, New York

Russo, Gian-Luigi, Dept. of Biochemistry, Istituto Scienze dell'Alimentazione, Avellino, Italy

RyeOM, SANDRA, Dept. of Cell Biology, Harvard University School of Medicine, Boston, Massachusetts

Sabapathy, Kanaga, Div. of Cellular and Molecular Research, National Cancer Centre, Singapore

SACCHI, NicoletTA, Dept. of Cancer Genetics, Roswell Park Cancer Institute, Buffalo, New York

SAFran, Michal, Dept. of Adult Oncology, Dana-Farber Cancer Institute, Boston, Massachusetts

SAito, Tsuyoshi, Dept. of Pathology, Memorial SloanKettering Cancer Center, New York, New York

SAnsal, IsABElle, Dept. of Medical Oncology, DanaFarber Cancer Institute, Boston, Massachusetts

Santarius, Thomas, Cancer Genome Project, The Wellcome Trust Sanger Institute, Hinxton, Cambridge, United Kingdom

SAPLIS, RACHEL, Dept. of Genetics, Cellular Biology, and Development, Cancer Center, University of Minnesota, Minneapolis

SARAMAKI, OUTI, Dept. of Cancer Genetics, Institute of Medical Technology, University of Tampere, Tampere, Finland

SAUNDERS, DARREN, Cancer Research Program, Garvan Institute of Medical Research, Darlinghurst, Sydney, New South Wales, Australia

SAunus, JodI, School of Molecular and Microbial Sciences, University of Queensland, St. Lucia, Australia

SAwYers, Charles, Dept. of Medicine, University of California, Los Angeles

SAYEed, SheikH, Dept. of Pharmacology and Therapeutics, Roswell Park Cancer Institute, Buffalo, New York

SCHAFFER, JAMES, Dept. of Healthcare Information Technology, Philips Research, Briarcliff Manor, New York

Schlegel, Robert, Dept. of Oncology, Novartis Institutes for BioMedical Research, Cambridge, Massachusetts

SCHLIEKELMAN, MARK, Dept. of Genetics, University of North Carolina, Chapel Hill

Schmitt, Clemens, Dept. of Hematology and Oncology, Max-Delbrück-Center for Molecular Medicine, Berlin, Germany

SCHNEIDER, GÜNTER, Dept. of Internal Medicine, Technical University of Munich, Munich, Germany

Schubert, Charlotte, Nature Medicine, Nature Publishing Group, New York, New York

SchweIZER, LiAng, Dept. of Oncology Drug Discovery, Bristol-Myers Squibb, Princeton, New Jersey

Scott, Clare, Cold Spring Harbor Laboratory, Cold Spring Harbor, New York

Sebastian, Thomas, Lab. of Protein Dynamics and Signaling, National Cancer Institute, Frederick, Maryland 
Selivanova, Galina, Microbiology and Tumor Biology Center, Karolinska Institute, Stockholm, Sweden

Sellers, William, Div. of Neoplastic Disease Mechanisms, Dana-Farber Cancer Institute, Harvard Medical School, Boston, Massachusetts

Serrano, Manuel, Centro Nacional de investigaciones Ontologica, Madrid, Spain

Shachaf, Catherine, Dept. of Medical Oncology, Stanford University, Stanford, California

Sherr, Charles, Dept. of Tumor Cell Biology, Howard Hughes Medical Institute, St. Jude Children's Research Hospital, Memphis, Tennessee

SHI, HuA, Dept. of Molecular Biology and Genetics, Cornell University, Ithaca, New York

SHIEH, SHEAU-YANN, Institute of Biomedical Sciences, Academia Sinica, Taipei, Taiwan, Republic of China

Shin, Hsiu-Ming, Institute of Biomedical Sciences, Academia Sinica, Taipei, Taiwan, Republic of China

ShIMIZU, TAKESHI, Dept. of Biochemistry and Molecular Biology, Pennsylvania State University, University Park, Pennsylvania

Shukla, NeERAV, Dept. of Pediatrics, Memorial SloanKettering Cancer Center, New York, New York

ShureIQI, IMAD, Dept. of Clinical Cancer Prevention, M.D. Anderson Cancer Center, University of Texas, Houston

SiBson, DAVID, J.K. Douglas Laboratories, Clatterbridge Cancer Research Trust, Clatterbridge Hospital, Bebington, Wirral, United Kingdom

Sidenius, Nicolai, Dept. of Transcriptional Mechanisms, FIRC Institute of Molecular Oncology Foundation, Milan, Italy

Silva, RiCARDO, Dept. of Hematology and Oncology, St. Jude Children's Research Hospital, Memphis, Tennessee

Silvestre, David, Dept. of Biological Chemistry, CIQUIBIC, National University of Córdoba, Córdoba, Argentina

SIMIN, KARL, Dept. of Genetics, Lineberger Comprehensive Cancer Center, University of North Carolina, Chapel Hill

Slack, Frank, Dept. of Molecular, Cellular, and Developmental Biology, Yale University, New Haven, Connecticut

Slamon, Dennis, Dept. of Medicine, Hematology and Oncology, University of California, Los Angeles

Slate, Doris, Dept. of Scientific Licensing, Johnson and Johnson Pharmaceutical Research and Development, San Diego, California

SLIWKOWSKI, MARK, Dept. of Translational Oncology, Genentech, Inc., South San Francisco, California

Small, Michael, Div. of Extramural Research, National Cancer Institute, National Institutes of Health, Bethesda, Maryland

Smirnov, Denis, Dept. of Research and Development, Immunicon Corp., Huntingdon Valley, Pennsylvania

Soengas, Maria, Dept. of Dermatology, University of Michigan, Ann Arbor

Song, Yurong, Dept. of Genetics, Lineberger Comprehensive Cancer Center, University of North Carolina, Chapel Hill

Sparmann, Anke, Dept. of Molecular Genetics, The
Netherlands Cancer Institute, Amsterdam, The Netherlands

Spector, David, Cold Spring Harbor Laboratory, Cold Spring Harbor, New York

Spector, Mona, Cold Spring Harbor Laboratory, Cold Spring Harbor, New York

Stewart, DAvid, Meetings and Courses Programs, Cold Spring Harbor Laboratory, Cold Spring Harbor, New York

Stillman, Bruce, President and CEO, Cold Spring Harbor Laboratory, Cold Spring Harbor, New York

Suh, Kwang, Lab. of Cellular Carcinogenesis and Tumor Promotion, National Cancer Institute, National Institutes of Health, Bethesda, Maryland

SukezAne, TAIKo, Lab. of Molecular Oncology, Osaka Bioscience Institute, Osaka, Japan

Swain, AmandA, Sect. of Gene Function and Regulation, Institute of Cancer Research, London, United Kingdom

Symons, MARC, Dept. of Oncology and Cell Biology, North Shore-Long Island Jewish Institute for Medical Research, Manhasset, New York

SÜltmanN, HolgER, Dept. of Molecular Genome Analysis, German Cancer Research Center, Heidelberg, Germany

TANAKA, Hisashi, Div. of Basic Sciences, Fred Hutchinson Cancer Research Center, Seattle, Washington

TARABAN, VADIM, Tenovus Research Laboratory, University of Southampton, Southampton, United Kingdom

Telerman, Adam, Dept. of Cancer Research, Molecular Engines Laboratories, Paris, France

TeraI, KentA, Dept. of Tumor Virology, Research Institute for Microbial Diseases, Osaka University, Osaka, Japan

TerZIAn, TAmara, Dept. of Molecular Genetics, Sect. of Cancer Genetics, M.D. Anderson Cancer Center, University of Texas, Houston

Tessier-Lavigne, Marc, Dept. of Research, Genentech, Inc., South San Francisco, California

Tews, BJoern, Dept. of Molecular Genetics, German Cancer Research Center, Heidelberg, Germany

Theillet, Charles, Genotypes et Phenotypes Tumoraux, INSERM, Montpellier, France

Thiagalingam, SAM, Dept. of Medicine and Genetics, Boston University School of Medicine, Boston, Massachusetts

Thompson, Craig, Abramson Family Cancer Research Institute, University of Pennsylvania, Philadelphia

Thuerigen, Dirk, Div. of Molecular Genetics, German Cancer Research Center, Heidelberg, Germany

Tlsty, TheA, Dept. of Pathology, School of Medicine, University of California, San Francisco

Traboni, Cinzia, Dept. of Biochemistry, Institute for Research in Molecular Biology, Pomezia, Italy

Treanor, Louise, Dept. of Pathology, Unversity of Edinburgh, Edinburgh, Scotland, United Kingdom

TsAi, HsIn-Yue, Dept. of Biochemistry, Ohio State University, Columbus, Ohio

TsE, ARCHIE, Dept. of Medicine, Memorial Sloan-Kettering Cancer Cancer, New York, New York

TsuchiHAshi, ZentA, Dept. of Pharmacogenomics, Bristol-Myers Squibb, Princeton, New Jersey 
TsuchiYa, NAото, Dept. of Biochemistry, National Cancer Center Research Institute, Tokyo, Japan

Tuveson, DAvid, Dept. of Hematology and Oncology, Abramson Family Cancer Research Institute, University of Pennsylvania, Philadelphia

Uren, Anthony, Dept. of Molecular Genetics, The Netherlands Cancer Institute, Amsterdam, The Netherlands

UzIEl, TAmar, Dept. of Tumor Cell Biology, St. Jude Children's Research Hospital, Memphis, Tennessee

VAfai, ScotT, Dept. of Cancer Biology, Dana-Farber Cancer Institute, Boston, Massachusetts

VAN DYCK, FREDERIK, Dept. of Human Genetics, Lab. for Molecular Oncology, University of Leuven, Leuven, Belgium

VAN DyKe, TERry, Dept. of Biochemistry, University of North Carolina, Chapel Hill

VAn Lohuizen, MAARTEN, Dept. of Moleular Genetics, The Netherlands Cancer Institute, Amsterdam, The Netherlands

VARMus, Harold, President and CEO, Memorial SloanKettering Cancer Center, New York, New York

Venkataraman, ChandraseKar, Dept. of Cancer Research, Eli Lilly and Company, Indianapolis, Indiana

Vigneron, Arnaud, Cancer Center Paul Papin, INSERM, Angers, France

VILENCHIK, MARIA, Dept. of Oncology, Hoffmann-La Roche, Inc., Nutley, New Jersey

Villanueva, Jessie, Dept. of Pharmacology, University of Pennsylvania, Philadelphia

Vincent, Sylvie, Dept. of Molecular Technology, AVEO Pharmaceuticals, Cambridge, Massachusetts

Vinson, Charles, Lab. of Metabolism, National Institutes of Health, Bethesda, Maryland

VREDEVELD, LIESBETH, Dept. of Molecular Genetics, The Netherlands Cancer Institute, Amsterdam, The Netherlands

Wallace, Douglas, Center for Molecular and Mitochondrial Medicine and Genetics, University of California, Irvine

WANG, GREG, Biomedical Sciences Program, School of Medicine, University of California at San Diego, La Jolla

WANG, Liang, Cold Spring Harbor Laboratory, Cold Spring Harbor, New York

WATNICK, RANDOLPH, Dept. of Surgery, Children's Hospital, Harvard Medical School, Boston, Massachusetts

WEI, GANG, Dept. of Tumorigenesis, Lankenau Institute for Medical Research, Wynnewood, Pennsylvania

Weinmann, Roberto, Dept. of Oncology Drug Discovery, Bristol-Myers Squibb, Princeton, New Jersey

WeinReich, Michael, Van Andel Research Institute, Grand Rapids, Michigan

Weissman, SHERMAn, Dept. of Genetics, Yale University School of Medicine, New Haven, Connecticut

Wendel, Hans-Guido, Cold Spring Harbor Laboratory, Cold Spring Harbor, New York

WERB, ZENA, Dept. of Anatomy, University of California, San Francisco

Westbrook, Trey, Dept. of Genetics, Harvard University School of Medicine, Boston, Massachusetts
WILKInSON, JoHN, Unit for Laboratory Animal Medicine, University of Michigan, Ann Arbor

Winter, ChristoPher, Dept. of Target Support and Validation, Merck Research Laboratories, Boston, Massachusetts

WitTe, Owen, Howard Hughes Medical Institute, Institute for Stem Cell Biology and Medicine, University of California, Los Angeles

Wong, SunNy, Dept. of Biology, Massachusetts Institute of Technology, Cambridge, Massachusetts

WORKMAN, PAUL, Dept. of Cancer Therapeutics, Institute of Cancer Research, Sutton, Surrey, United Kingdom

Xia, MingXuan, Dept. of Biomedical Genetics, University of Rochester Medical Center, Rochester, New York

XIOng, Yue, Dept. of Biochemistry and Biophysics, University of North Carolina, Chapel Hill

Xu, Jun, Dept. of Oncology Research, Wyeth, Pearl River, New York

XU, LEI, Center for Cancer Research, Massachusetts Institute of Technology, Cambridge, Massachusetts

Xu, QInG, Dept. of Medical Oncology, Dana-Farber Cancer Institute, Boston, Massachusetts

Xu, Rui-Ming, Cold Spring Harbor Laboratory, Cold Spring Harbor, New York

Xu, XINGZHI, Dept. of Biology, Beckman Research Institute, City of Hope Medical Center, Duarte, California

YAMACI, REZAN, Dept. of Molecular Biology and Genetics, Bogazici University, Istanbul, Turkey

Yamada, N. Alice, Dept. of Biosciences, Lawrence Livermore National Laboratory, Livermore, California

YAMASAKI, LILI, Dept. of Biological Sciences, Columbia University, New York, New York

Yancopoulos, George, Regeneron Pharmaceuticals, Inc., Tarrytown, New York

YANG, QUAN, Dept. of Therapeutics, IBEX Pharmaceuticals, Inc.,Montréal, Québec, Canada

Yarden, Ronit, Dept. of Surgical Oncology, Chaim Sheba Medical Center, Tel-Hashomer, Israel

YIM, Sun HEE, Lab. of Metabolism, National Cancer Institute, National Institutes of Health, Bethesda, Maryland

Yoon, Sung OK, Dept. of Cellular Immunology, Ochsner Clinic Foundation, Jefferson, Louisiana

ZENDER, LARS, Cold Spring Harbor Laboratory, Cold Spring Harbor, New York

Zhang, HongBing, Dept. of Hematology, Brigham and Women's Hospital, Harvard Medical School, Boston, Massachusetts

ZHANG, QIAN, Dept. of Genetics, Biochemistry, and Biophysics, Lineberger Comprehensive Cancer Center, University of North Carolina, Chapel Hill

Zhang, Xiaoshan, Dept. of Molecular Genetics, M.D. Anderson Cancer Center, University of Texas, Houston

ZHANG, YANPING, Dept. of Radiation Oncology, University of North Carolina, Chapel Hill

Zhou, ZongXiang, Dept. of Biomedical Sciences, Cornell University, Ithaca, New York

VAN DER MEIJden, CARoline, Cold Spring Harbor Laboratory, Cold Spring Harbor, New York

van de Wetering, Christopher, Dept. of Pathology, University of Iowa Hospitals and Clinics, Iowa City 

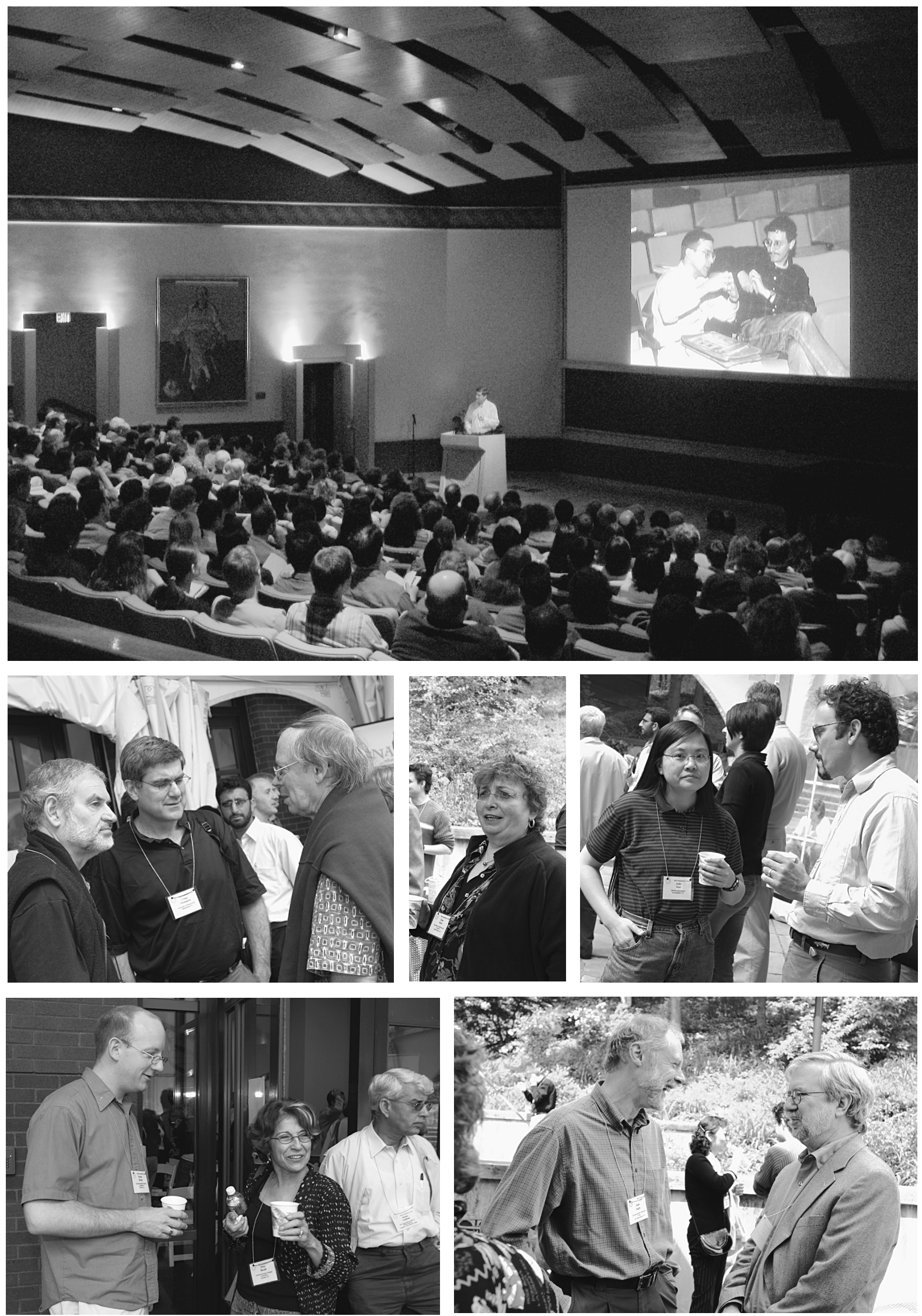

First row: Craig Thompson delivering eulogy for Stanley Korsmeyer (on screen, S. Korsmeyer $[l]$ and M. Hengartner $[r]$ ) Second row: R. Eisenman, C. Thompson, and J. Adams; Z. Werb; J. Kan, G. Borzilllo Third row: P. Kenny, M. Bissell, M. Godbole; J. Inglis, J. Allison 

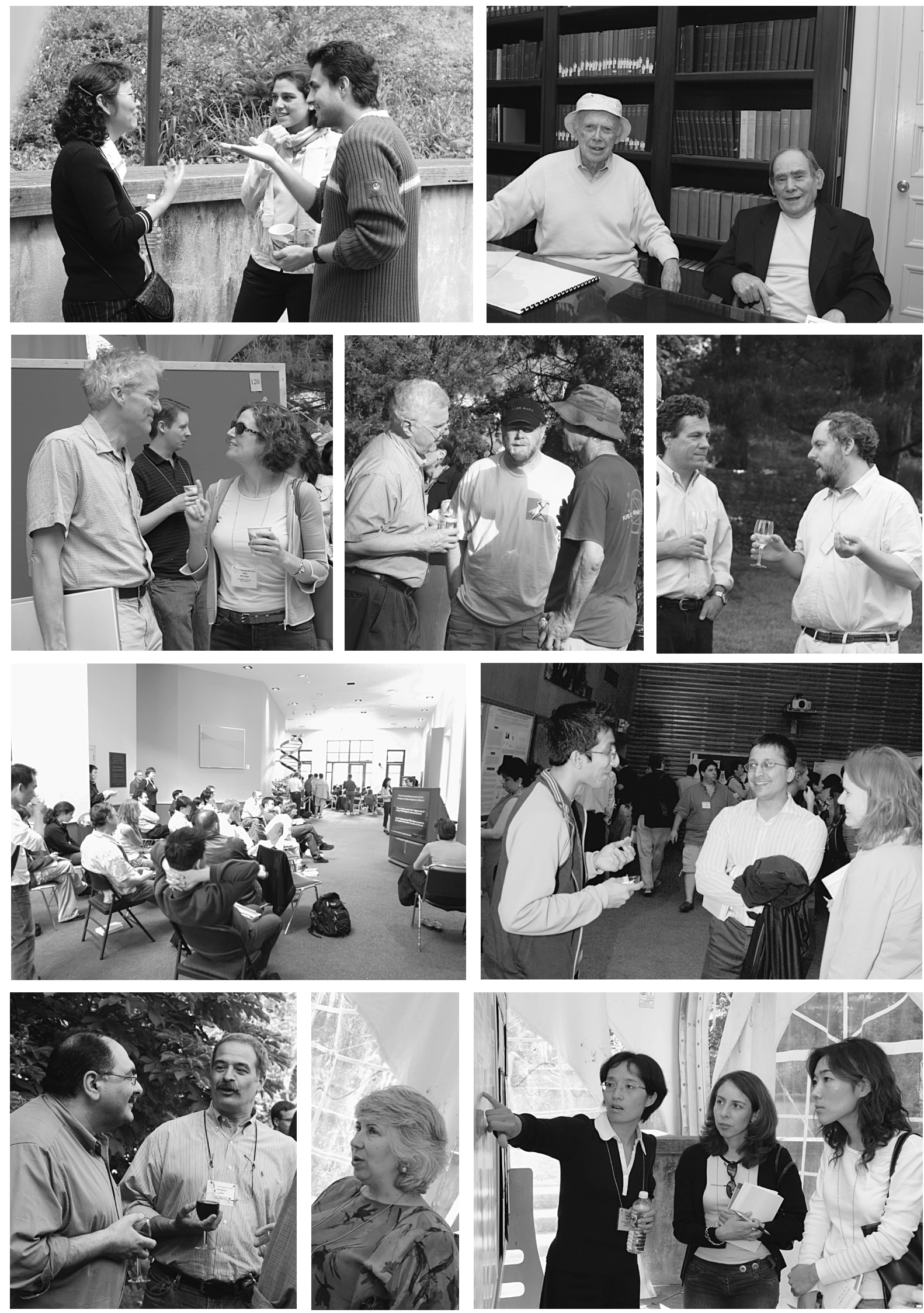

First row: L. Schweizer, R. Scotillo, M. Jechlinger; J.D. Watson, S. Brenner

Second row: R. Bernards, T. de Lange; B. Alberts, E. Harlow, H. Varmus; S. Lowe, S. Elledge Third row: Watching Symposium in Grace lobby; G. Gupta, P. Gupta, R. Saplis Fourth row: G. Enikolopov, R. Attar; T. Tlsty; Y. Song, S.O. Yoon, J. Villanueva 

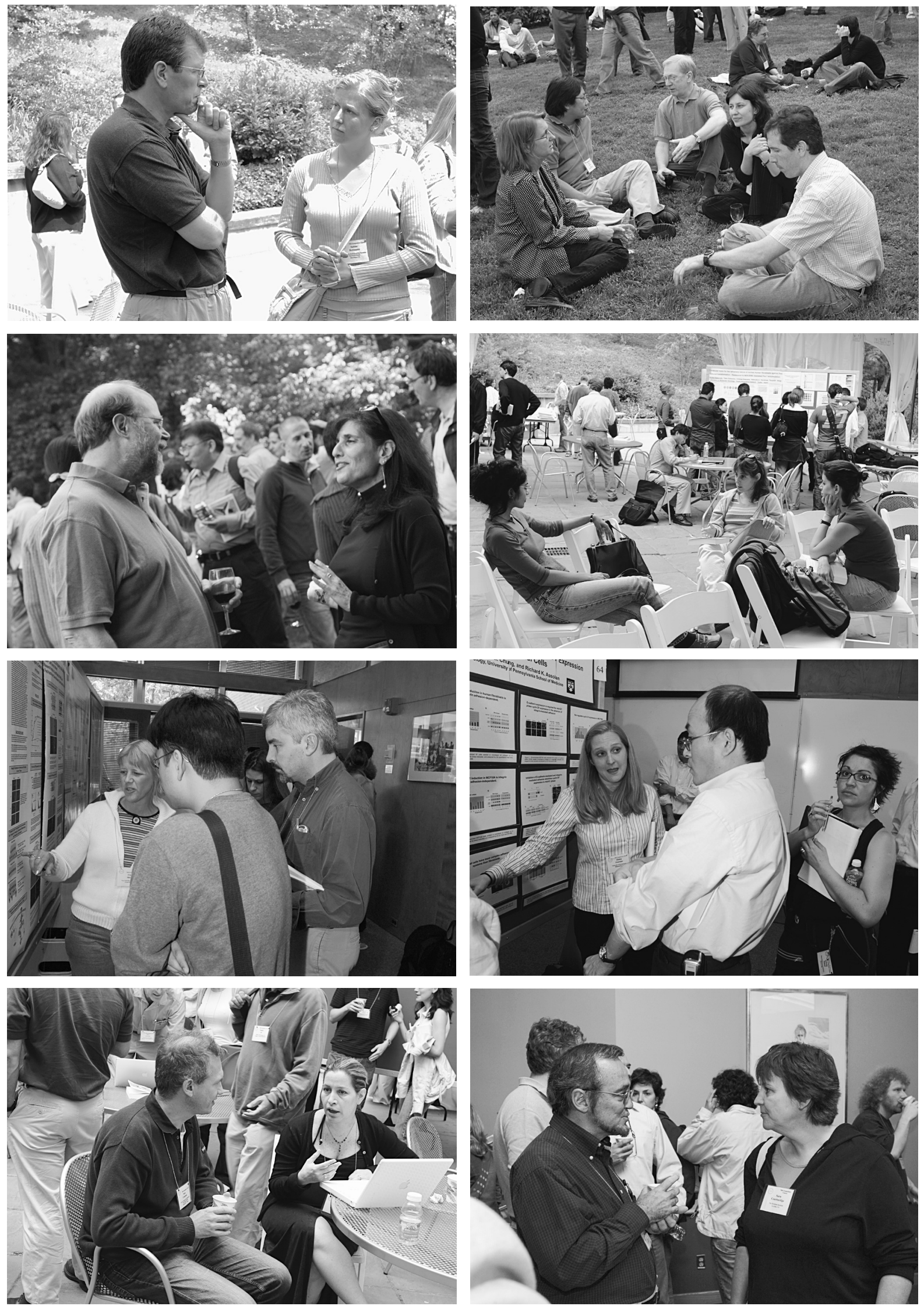

First row: B. Luscher, S. Rottmann; C. Schubert, K. Quon, G. Peters, C. Martins, M. Fero Second row: E. Harlow, D. Esposito; Under the tent

Third row: C. Miranti, S. Wong, E. Medico; A. Fournier, H.-G. Kang, I. Sansal

Fourth row: P. Coopman, R. Yarden; M. Barbacid, S. Courtneidge 
Downloaded from symposium.cshlp.org on April 26, 2023 - Published by Cold Spring Harbor Laboratory Press
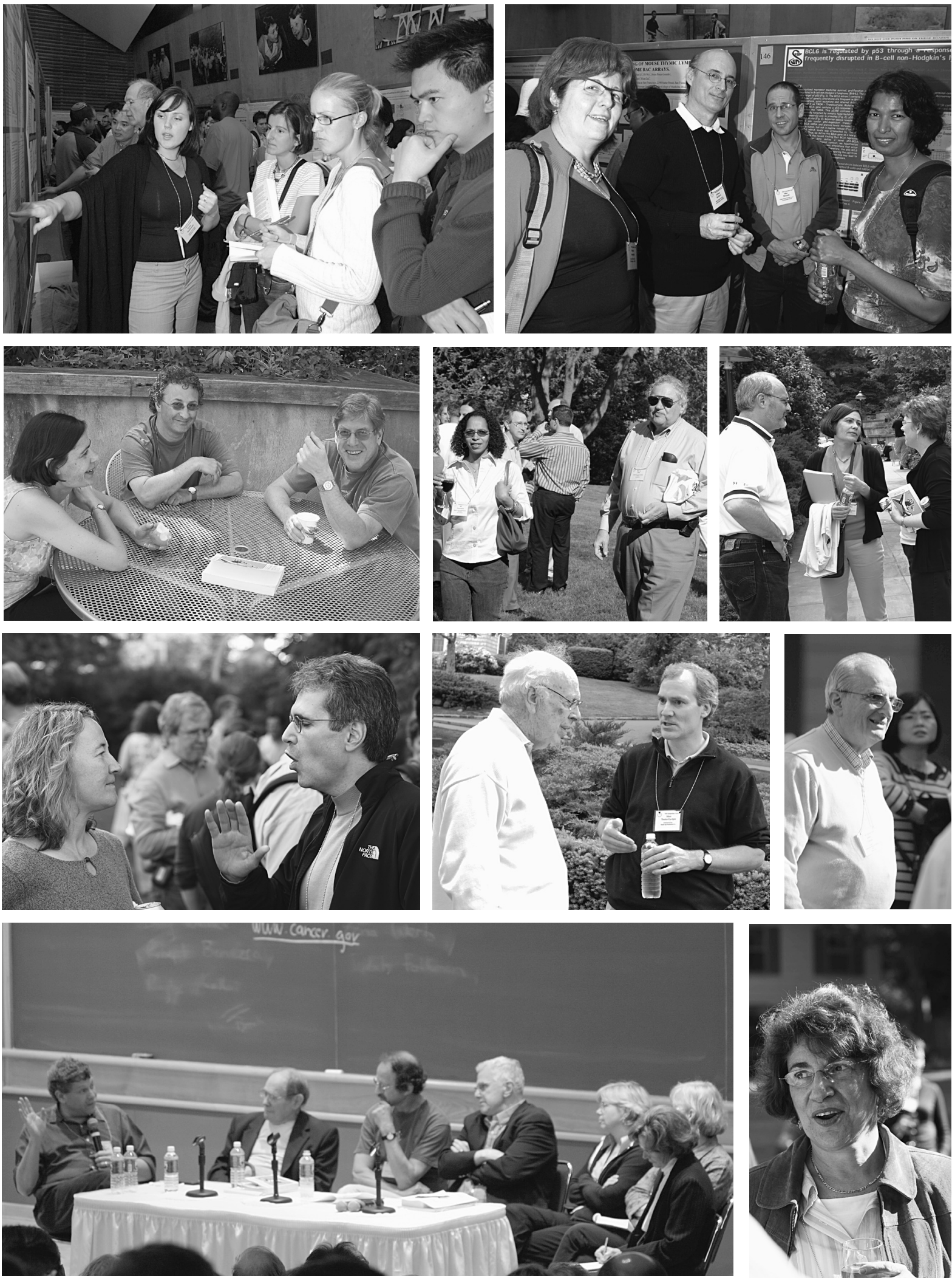

First row: G. MacDonald, S. Benvenuti, J. Saunus, K. Chan; C. Shachaf, O. Margalit, G. Rechavi, N. Amariglio Second row: J. Lees, G. Evan, C. Sherr; J. Bargonetti, H. Ozer; M. Kastan, J. Lees, T. Van Dyke Third row: C. Greider, R. DePinho; J.D. Watson, M. Tessier-Lavigne; J. Folkman

Fourth row: Cancer Genome Project Discussion Panel $(l-r)$ E. Lander, S. Brenner, H. Varmus, B. Alberts, J. Brugge, J. Peterson, A. Barker; C. Prives 
Downloaded from symposium.cshlp.org on April 26, 2023 - Published by Cold Spring Harbor Laboratory Press
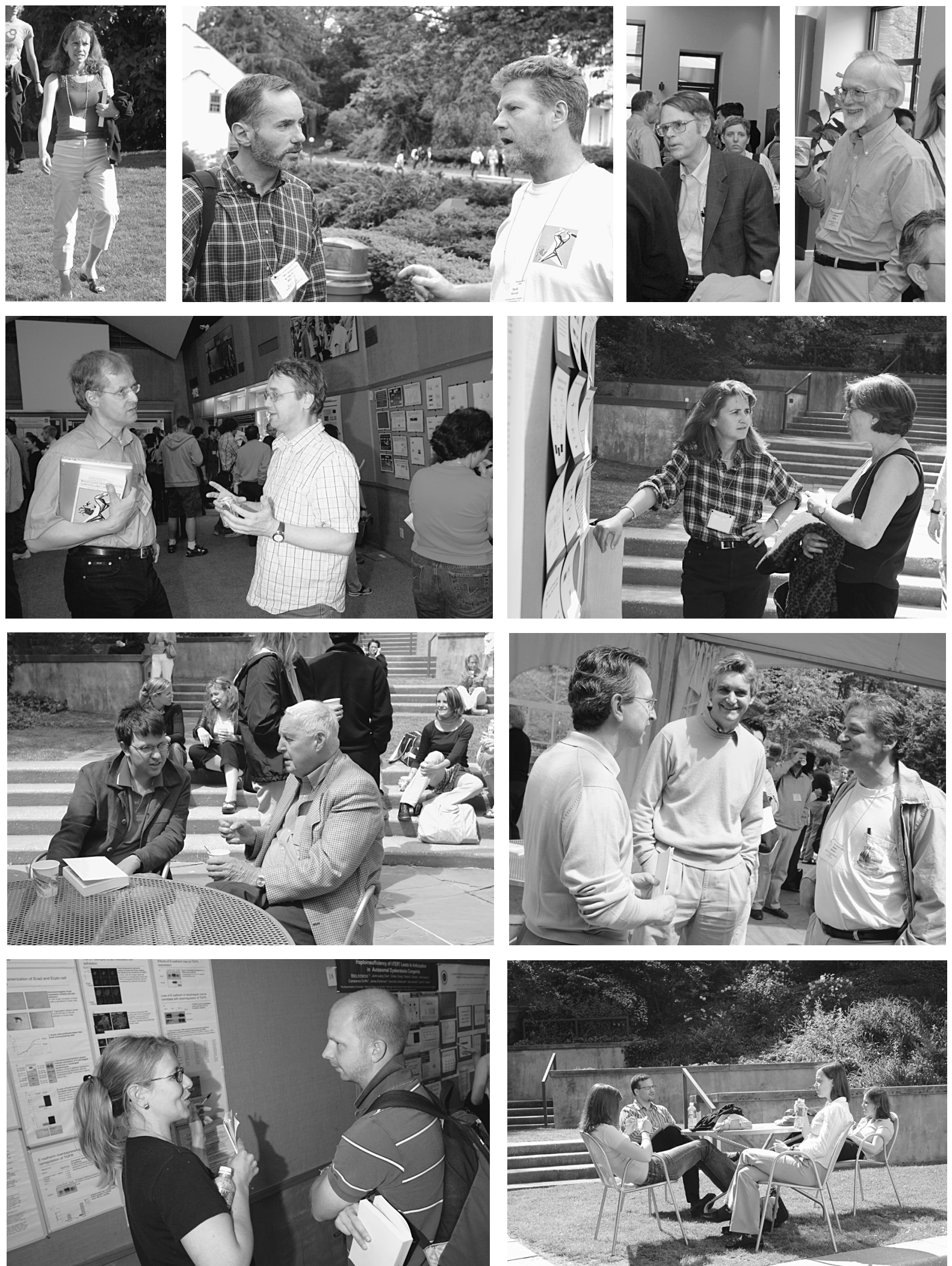

First row: L. Attardi; K. Hillan, D. Stewart, sporting the Symposium T-shirt; D. Wallace; M. Bishop Second row: M. Eilers, M. Van Lohuizen; A. Gradi, N. Sacchi

Third row: H.-G. Wendell, B. Clarkson; J. Massagué, B. Stillman, R. Benezra

Fourth row: C. Andl, D. Thuerigen; M. Hickey, K. Olive, K. Covello, M. Gruber 

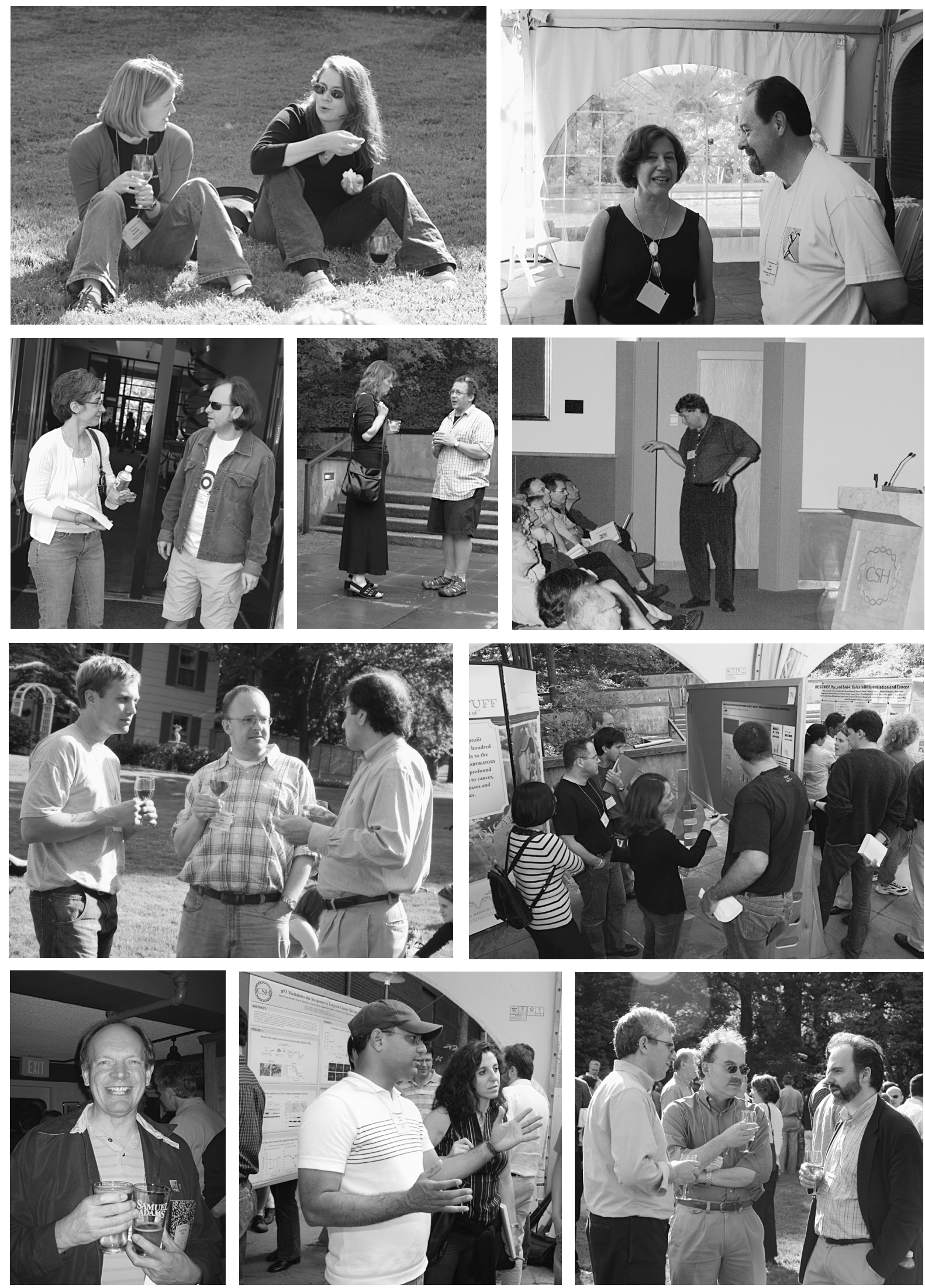

First row: H. Rauhala, O. Saramaki; N. Sacchi, L. Parada

Second row: A. Ballesteros, A. Ashworth; B. Marte, G. Hannon; E. Lander Third row: B. Tews, M. Hahn, D. Spector; Posters under the tent

Fourth row: D. Lane; R. Kalluri; M. Meyerson, D. Haber, M. Ladanyi 

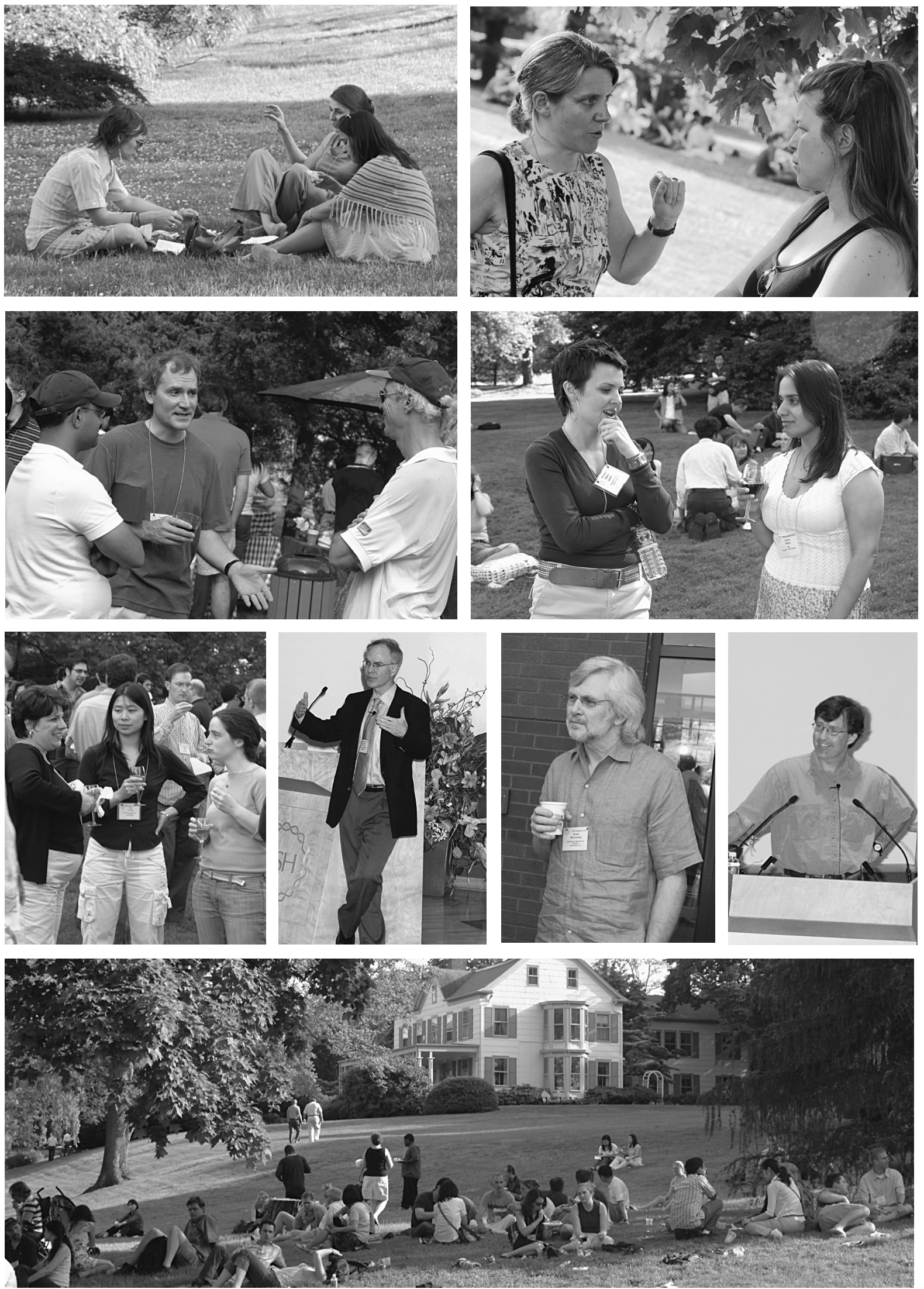

First row: G. Poortinga, C. Billottet, A. Majid; C. Scott, S. Smith

Second row: R. Kalluri, M. Tessier-Lavigne, D. Hanahan; A. Majid, M. Junttila

Third row: C. Abate-Shen, A. Cheung, K. Lane; C. Sawyers, Dorcas Cummings Lecture; F. McCormick; T. Jacks giving Summary Fourth row: Symposium picnic 


\section{Dedication}

Stan Korsmeyer passed away on March 31, 2005, at the age of 54. Ironically, he died of lung cancer. He had been looking forward to attending this meeting focused on molecular approaches to controlling cancer, a subject he dedicated his life to. Despite being gravely ill, he registered for the meeting. In the meeting book, he is listed as one of the participants and, in spirit, he was.

Stan grew up on a hog farm in southern Illinois. He did not start out to be a research scientist. In college, he became interested in science and decided to go to medical school. He went through internship and residency at the University of California, San Francisco, followed by a fellowship at the NIH. He arrived in Bethesda at the time when physicians were first learning molecular biology and applying it to cancer research. In those days, the cancer research meeting was the Cold Spring Harbor Symposium on Viral Oncogenes. It was through the scientific exchange at that meeting that Stan and others in the community came to re-

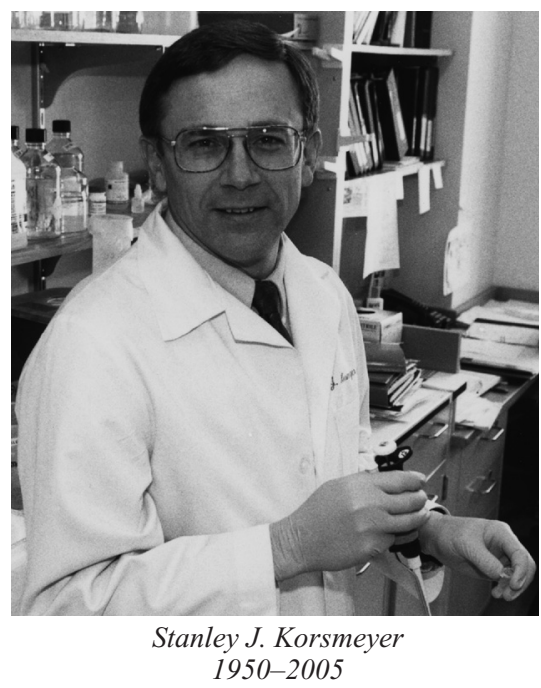
alize that chromosomal translocations might represent oncogenic events that could be molecularly characterized. Stan started working on this problem as a postdoctoral fellow in the laboratories of Phil Leder and Tom Waldman. Armed with that training, he joined the faculty at Washington University in St. Louis as an assistant professor. Stan did not start out as a central figure in the outstanding hematology and oncology faculty assembled there by Stuart Kornfield. Stan stood at the edge of that group, bridging it to molecular biology. However, even then, Stan was quickly moving to the center of our community. By characterizing chromosomal translocations, Stan's laboratory was one of the groups that cloned the oncogenes Bcl-2 and MLL. By the time of the 1994 CSHL Symposium on Cancer, Stan's work led many of us to consider the role of apoptosis in cancer. That was the first meeting where we started to discuss whether the regulation of programmed cell death played a critical role in the pathogenesis of cancer. Stan believed understanding apoptosis might contribute to new therapies for cancer.

Stan's work over the next few years brought him to the leading edge of biology. His groundbreaking work defining the Bcl-2 family members as interactive partners controlling the rheostat of apoptosis moved him to center stage. In 1998, Stan was recruited to Harvard University to nucleate a research program in apoptosis. With his positive and interactive personality, he quickly became a leader at the Dana-Farber Cancer Center.

At every scientific meeting, Stan was the one asking the probing questions and suggesting collaborations that would lead to the answers to those questions. Stan had that unique capability of organizing people, focusing them on the activity at hand, and, even though they'd never done it before, giving them the skills to go out and do research on the murky waters of cancer biology.

In closing, we remember him as a friend, colleague, and a real leader in this community, and for the positive interactions that he spurred within the cancer biology community. It is in that spirit that CSHL dedicates this volume to his memory. 


\section{Foreword}

During the past quarter century or so, much effort has been devoted toward the understanding of the molecular basis of cancer. We now understand that cancer is primarily a genetic disease of mutations in the tumor genome acquired over a lifetime. The products of oncogenes and tumor suppressor genes have been placed into pathways of gene networks that are altered in tumor cells compared to normal cells in tissue. Furthermore, we also understand that tumors function as abnormal organs, forming an architecture of a number of different cell types and recruiting a blood supply, albeit an irregular one. There have been many Symposia in this series that dealt with cancer directly, and even more that focused on basic biology that contributed greatly to understanding cancer.

As a result of some interesting developments in cancer diagnosis and therapy over the past five years, it was appropriate that a Symposium be devoted for the first time to molecular approaches to cancer therapy. Several examples now exist of targeted therapy that works in patients that have been profiled based on genetic diagnosis of the patient's tumor. Additionally, therapies targeting the tumor as an organ, such as anti-angiogenic therapy, are now used in the clinic with modest success. The hope is that this type of molecular approach to cancer therapy will accelerate and become more effective in the future.

In organizing this Symposium with help from Terri Grodzicker, we relied on the assistance of a number of colleagues for suggestions for speakers. They included David Livingston, Craig Thompson, and Scott Lowe, and we thank them for their valuable advice. We also thank the first evening speakers, Dennis Slamon, Harold Varmus, Mina Bissell, and Jim Allison, for providing an overview of the areas to be covered. This year's Reginald Harris Lecture was delivered by Titia de Lange on telomere biology and genomic stability. We particularly thank Tyler Jacks for delivering a thoughtful and realistic summary of where we are in relation to our goal. Charles Sawyers, who conveyed the excitement which many of us feel knowing that some inroads into treating cancer will be made by targeted therapies, presented the Dorcas Cummings Lecture to the local community and the attending scientists. The effort put into the Dorcas Cummings Lecture by Charles and the summary by Tyler resulted in highlights of the meeting.

This Symposium was attended by 515 scientists and clinicians, and the program included 71 oral presentations and 241 poster presentations. Bruce Alberts chaired a discussion of the proposal to analyze the genomes of all major human cancers to advance cancer diagnosis and therapy approaches.

Essential funds to run this meeting were obtained from the National Cancer Institute, a branch of the National Institutes of Health. In addition, financial help from the corporate benefactors, sponsors, affiliates, and contributors of our meetings program is essential for these Symposia to remain a success, and we are most grateful for their continued support.

We thank Val Pakaluk and Mary Smith in the Meetings and Courses office for their efficient help in organizing the Symposium. Joan Ebert, Patricia Barker, and Susan Schaefer in the Cold Spring Harbor Laboratory Press, headed by John Inglis, ensured that this volume would be produced. We thank them for their dedication to producing high-quality publications.

Bruce Stillman

David Stewart

April 2006 


\section{Sponsors}

This meeting was funded in part by the National Cancer Institute, a branch of the National Institutes of Health.

Contributions from the following companies provide core support for the Cold Spring Harbor meetings program.

\section{Corporate Benefactors}

Amgen, Inc.

Bristol-Myers Squibb Company

\section{Corporate Sponsors}

Applied Biosystems

AstraZeneca

BioVentures, Inc.

Diagnostic Products Corporation

Forest Laboratories, Inc.

Genentech, Inc.

Hoffmann-La Roche, Inc.

Johnson \& Johnson Pharmaceutical

Research \& Development, L.L.C.

\section{Plant Corporate Associates}

ArborGen

Monsanto Company

\section{Corporate Affiliates}

Affymetrix, Inc.

Agencourt Biosciences

\section{Corporate Contributors}

Aviva Systems Biology

Biogen, Inc.

EMD Bioscience

\section{Foundations}

Albert B. Sabin Vaccine Institute, Inc. Hudson Alpha Institute for Biotechnology
GlaxoSmithKline

Novartis Institutes for BioMedical Research

Kyowa Hakko Kogyo Co., Ltd.

Lexicon Genetics, Inc.

Merck Research Laboratories

New England BioLabs, Inc.

OSI Pharmaceuticals, Inc.

Pall Corporation

Schering-Plough Research Institute

Wyeth Genetics Institute
Illumina

IRx Therapeutics, Inc.

Qiagen 


\section{Contents}

Symposium Participants $\quad$ v

Dedication $\quad$ xxiii

Foreword $\quad$ xxv

\section{Cancer Genetics and Genomes}

Oncogenes Come of Age H. Varmus, W. Pao, K. Politi, K. Podsypanina, and Y.-C.N. Du

Common and Contrasting Genomic Profiles among the Major Human Lung Cancer Subtypes G. Tonon, C. Brennan, A. Protopopov, G. Maulik, B. Feng, Y. Zhang, D.B. Khatry, M.J. You, A.J. Aguirre, E.S. Martin, Z. Yang, H. Ji, L. Chin, K.-K. Wong, and R.A. DePinho

"Lineage Addiction" in Human Cancer: Lessons from Integrated Genomics L.A. Garraway, B.A. Weir, X. Zhao, H. Widlund, R. Beroukhim, A. Berger, D. Rimm, M.A. Rubin, D.E. Fisher, M.L. Meyerson, and W.R. Sellers

Polygenic Inherited Predisposition to Breast Cancer B.A.J. Ponder, A. Antoniou, A. Dunning, D.F. Easton, and P.D.P. Pharoah

Somatic Mutations in Human Cancer: Insights from Resequencing the Protein Kinase Gene Family P.A. Futreal, R. Wooster, and M.R. Stratton

High-Resolution ROMA CGH and FISH Analysis of Aneuploid and Diploid Breast Tumors

J. Hicks, L. Muthuswamy, A. Krasnitz, N. Navin, M. Riggs, V. Grubor, D. Esposito,

J. Alexander, J. Troge, M. Wigler, S. Maner, P. Lundin, and A. Zetterberg

Ductal Pancreatic Cancer in Humans and Mice D.A. Tuveson and S.R. Hingorani

Detection of Oncogenic Mutations in the EGFR Gene in Lung Adenocarcinoma with Differential Sensitivity to EGFR Tyrosine Kinase Inhibitors R.K. Thomas, H. Greulich, Y. Yuza, J.C. Lee, T. Tengs, W. Feng, T.-H. Chen, E. Nickerson, J. Simons, M. Egholm, J.M. Rothberg, W.R. Sellers, and M.L. Meyerson

Two Decades of Cancer Genetics: From Specificity to Pleiotropic Networks S. Grisendi and P.P. Pandolfi

\section{DNA Damage Response}

Abnormalities of the Inactive X Chromosome Are a Common Feature of BRCA1 Mutant and Sporadic Basal-like Breast Cancer S. Ganesan, A.L. Richardson, Z.C. Wang, J.D. Iglehart, A. Miron, J. Feunteun, D. Silver, and D.M. Livingston

Single-Nucleotide Polymorphisms in the p53 Pathway S.L. Harris, G. Gil, W. Hu, H. Robins, E. Bond, K. Hirshfield, Z. Feng, X. Yu, A.K. Teresky, G. Bond, and A.J. Levine

Transcriptional Regulation by 53 and p73 M. Lokshin, T. Tanaka, and C. Prives

p53-Dependent and -Independent Functions of the Arf Tumor Suppressor C.J. Sherr, D. Bertwistle, W. den Besten, M.-L. Kuo, M. Sugimoto, K. Tago, R.T. Williams, F. Zindy, and M.F. Roussel

Exploiting the DNA Repair Defect in BRCA Mutant Cells in the Design of New Therapeutic Strategies for Cancer A.N.J. Tutt, C.J. Lord, N. McCabe, H. Farmer, N. Turner, N.M. Martin, S.P. Jackson, G.C.M. Smith, and A. Ashworth

\section{Cancer Biology and Stem Cells}

Identifying Site-specific Metastasis Genes and Functions G.P. Gupta, A.J. Minn, Y. Kang, P.M. Siegel, I. Serganova, C. Cordón-Cardo, A.B. Olshen, W.L. Gerald, and J. Massagué

The von Hippel-Lindau Tumor Suppressor Protein: Roles in Cancer and Oxygen Sensing W.G. Kaelin, Jr.

The Src Substrate Tks5, Podosomes (Invadopodia), and Cancer Cell Invasion S.A. Courtneidge, E.F. Azucena, Jr., I. Pass, D.F. Seals, and L. Tesfay 
Modeling Neurofibromatosis Type 1 Tumors in the Mouse for Therapeutic Intervention L.F. Parada, C.-H. Kwon, and Y. Zhu

Stem Cell Self-Renewal and Cancer Cell Proliferation Are Regulated by Common Networks That Balance the Activation of Proto-oncogenes and Tumor Suppressors R. Pardal, A.V. Molofsky, S. He, and S.J. Morrison

Prostate Stem Cells and Prostate Cancer D.A. Lawson, L. Xin, R. Lukacs, Q. Xu, D. Cheng, and O.N. Witte

\section{Telomeres, Senescence, and Aging}

Telomere-related Genome Instability in Cancer T. de Lange

Telomerase and Cancer Stem Cells M. Armanios and C.W. Greider

Regulation of Telomerase by Human Papillomaviruses D.A. Galloway, L.C. Gewin, H. Myers, W. Luo, C. Grandori, R.A. Katzenellenbogen, and J.K. McDougall

\section{Animal Models for Cancer}

Genomic Progression in Mouse Models for Liver Tumors A.D. Tward, K.D. Jones, S. Yant, M.A. Kay, R. Wang, and J.M. Bishop

Genotype-Phenotype Relationships in a Mouse Model for Human Small-Cell Lung Cancer J. Calbó, R. Meuwissen, E. van Montfort, O. van Tellingen, and A. Berns

Cell Cycle and Cancer: Genetic Analysis of the Role of Cyclin-dependent Kinases M. Barbacid, S. Ortega, R. Sotillo, J. Odajima, A. Martín, D. Santamaría, P. Dubus, and M. Malumbres

Mouse Models of Human Non-Small-Cell Lung Cancer: Raising the Bar C.F.B. Kim, E.L. Jackson, D. G. Kirsch, J. Grimm, A.T. Shaw, K. Lane, J. Kissil, K.P. Olive, A. Sweet-Cordero, R. Weissleder, and T. Jacks

Generation and Analysis of Genetically Defined Liver Carcinomas Derived from Bipotential Liver Progenitors L. Zender, W. Xue, C. Cordón-Cardo, G.J. Hannon, R. Lucito, S. Powers, P. Flemming, M.S. Spector, and S.W. Lowe

Oncogene-dependent Tumor Suppression: Using the Dark Side of the Force for Cancer Therapy G.I. Evan, M. Christophorou, E.A. Lawlor, I. Ringshausen, J. Prescott, T. Dansen, A. Finch, C. Martins, and D. Murphy

Chromosomal Translocation Engineering to Recapitulate Primary Events of Human Cancer A. Forster, R. Pannell, L. Drynan, F. Cano, N. Chan, R. Codrington, A. Daser, N. Lobato, M. Metzler, C.-H. Nam, S. Rodriguez, T. Tanaka, and T. Rabbitts

Deciphering Cancer Complexities in Genetically Engineered Mice K. Simin, R. Hill, Y. Song, Q. Zhang, R. Bash, R.D. Cardiff, C. Yin, A. Xiao, K. McCarthy, and T. Van Dyke

\section{Gene Expression and Cancer}

The Evolving Portrait of Cancer Metastasis P.B. Gupta, S. Mani, J. Yang, K. Hartwell, and R.A. Weinberg

Genomic Binding and Transcriptional Regulation by the Drosophila Myc and Mnt Transcription Factors A. Orian, S.S. Grewal, P.S. Knoepfler, B.A. Edgar, S.M. Parkhurst, and R.N. Eisenman

Regulation of the Arf/p53 Tumor Surveillance Network by E2F P.J. Iaquinta, A. Aslanian, and J.A. Lees

Genetic and Epigenetic Changes in Mammary Epithelial Cells Identify a Subpopulation of Cells Involved in Early Carcinogenesis H. Berman, J. Zhang, Y.G. Crawford, M.L. Gauthier, C.A. Fordyce, K. McDermott, M. Sigaroudinia, K. Kozakiewicz, and T.D. Tlsty

\section{Tumor Responses to Microenvironment}

Microenvironmental Regulators of Tissue Structure and Function Also Regulate Tumor Induction and Progression: The Role of Extracellular Matrix and Its Degrading Enzymes M.J. Bissell, P.A. Kenny, and D.C. Radisky 
How Do Cancer Cells Acquire the Fuel Needed to Support Cell Growth? C.B. Thompson,

D.E. Bauer, J.J. Lum, G. Hatzivassiliou, W.-X. Zong, D. Ditsworth, F. Zhao, M. Buzzai, and T. Lindsten

Mitochondria and Cancer: Warburg Addressed D.C. Wallace

Inductions of Complete Regressions of Oncogene-induced Breast Tumors in Mice R. Benezra,

E. Henke, A. Ciarrocchi, M. Ruzinova, D. Solit, N. Rosen, D. Nolan, V. Mittal, and P. de Candia

The Fibroblastic Coconspirator in Cancer Progression M. Egeblad, L.E. Littlepage, and Z. Werb

\section{Angiogenesis}

Is Oncogene Addiction Angiogenesis-dependent? J. Folkman and S. Ryeom

Structural Basis for the Functions of Endogenous Angiogenesis Inhibitors M.A. Grant and R. Kalluri

VEGF Trap as a Novel Antiangiogenic Treatment Currently in Clinical Trials for Cancer and Eye Diseases, and VelociGene-based Discovery of the Next Generation of Angiogenesis Targets J.S. Rudge, G. Thurston, S. Davis, N. Papadopoulos, N. Gale, S.J. Wiegand, and G.D. Yancopoulos

\section{Discovering Cancer Targets}

Molecular Targeted Therapy of Lung Cancer: EGFR Mutations and Response to EGFR Inhibitors D.A. Haber, D.W. Bell, R. Sordella, E.L. Kwak, N. Godin-Heymann, S.V. Sharma, T.J. Lynch, and J. Settleman

Aberrant Gene Silencing in Tumor Progression: Implications for Control of Cancer S.B. Baylin and W.Y. Chen

Dissecting Cancer Pathways and Vulnerabilities with RNAi T.F. Westbrook, F. Stegmeier, and S.J. Elledge

Emerging Approaches in Molecular Profiling Affecting Oncology Drug Discovery S.H. Friend

Screens Using RNAi and cDNA Expression as Surrogates for Genetics in Mammalian Tissue Culture Cells J. Pearlberg, S. Degot, W. Endege, J. Park, J. Davies, E. Gelfand, J. Sawyer, A. Conery, J. Doench, W. Li, L. Gonzalez, F.M. Boyce, L. Brizuela, J. LaBaer, D. Grueneberg, and E. Harlow

Cancer Targets in the Ras Pathway P. Rodriguez-Viciana, O. Tetsu, K. Oda, J. Okada, K. Rauen, and F. McCormick

\section{Therapeutic Approaches}

Subversion of the Bcl-2 Life/Death Switch in Cancer Development and Therapy J.M. Adams,

D.C.S. Huang, A. Strasser, S. Willis, L. Chen, A. Wei, M. Van Delft, J.I. Fletcher,

H. Puthalakath, J. Kuroda, E.M. Michalak, P.N. Kelly, P. Bouillet, A. Villunger, L. O’Reilly,

M.L. Bath, D.P. Smith, A. Egle, A.W. Harris, M. Hinds, P. Colman, and S. Cory

Making Progress through Molecular Attacks on Cancer C.L. Sawyers

Predicting Clinical Benefit in Non-Small-Cell Lung Cancer Patients Treated with Epidermal Growth Factor Tyrosine Kinase Inhibitors L.C. Amler, A.D. Goddard, and K.J. Hillan

Exploiting the p53 Pathway for the Diagnosis and Therapy of Human Cancer D.P. Lane

Drugging the Cancer Kinome: Progress and Challenges in Developing Personalized Molecular Cancer Therapeutics P. Workman

Modeling of Protein Signaling Networks in Clinical Proteomics D.H. Geho, E.F. Petricoin, L.A. Liotta, and R.P. Araujo 


\section{$8_{8}^{\infty} \mathrm{CSH} \&$ Cold Spring Harbor Symposia SYMPOSIA on Quantitative Biology}

\section{Molecular Approaches to Controlling Cancer}

Cold Spring Harb Symp Quant Biol 2005 70: i-xxix

Access the most recent version at doi:10.1101/sqb.2005.70.060

\section{License}

Email Alerting Receive free email alerts when new articles cite this article - sign up in Service the box at the top right corner of the article or click here. 